\title{
Glutamate-induced Calcium Transient Triggers Delayed Calcium Overload and Neurotoxicity in Rat Hippocampal Neurons
}

\author{
Robert D. Randall ${ }^{\mathrm{a}}$ and Stanley A. Thayer \\ Department of Pharmacology, University of Minnesota Medical School, Minneapolis, Minnesota 55455
}

Glutamate-induced changes in intracellular free $\mathrm{Ca}^{2+}$ concentration $\left(\left[\mathrm{Ca}^{2+}\right]_{i}\right)$ were recorded in single rat hippocampal neurons grown in primary culture by employing the $\mathrm{Ca}^{2+}$ indicator indo-1 and a dual-emission microfluorimeter. The $\left[\mathrm{Ca}^{2+}\right]$ was monitored in neurons exposed to $100 \mu \mathrm{M}$ glutamate for $5 \mathrm{~min}$ and for an ensuing $3 \mathrm{hr}$ period. Ninety-two percent ( $n=64$ ) of these neurons buffered the glutamateinduced $\mathrm{Ca}^{2+}$ load back to basal levels after removal of the agonist; thus, the majority of cells had not lost the ability to regulate $\left[\mathrm{Ca}^{2+}\right]$ at this time. However, following a variable delay, in $44 \%(n=26)$ of the neurons that buffered glutamate-induced $\mathrm{Ca}^{2+}$ loads to basal levels, $\left[\mathrm{Ca}^{2+}\right]$, rose again to a sustained plateau and failed to recover. The changes in $\left[\mathrm{Ca}^{2+}\right]$, that occur during glutamate-induced delayed neuronal death can be divided into three phases: (1) a triggering phase during which the neuron is exposed to glutamate and

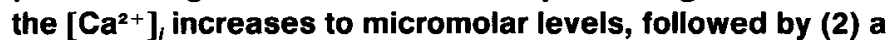
latent phase during which the $\left[\mathrm{Ca}^{2+}\right]$, recovers to a basal level, and (3) a final phase that begins with a gradual rise in the $\left[\mathrm{Ca}^{2+}\right]_{i}$ that reaches a sustained plateau from which the neuron does not recover. This delayed $\mathrm{Ca}^{2+}$ overload phase correlated significantly with cell death. The same sequence of events was also observed in recordings from neuronal processes. The delayed $\mathrm{Ca}^{2+}$ increase and subsequent death were dependent upon the presence of extracellular $\mathrm{Ca}^{2+}$ during glutamate exposure. Calcium influx during the triggering phase resulted from the activation of both NMDA and non-NMDA receptors as indicated by studies using receptor antagonists and ion substitution. Treatment with TTX $(1 \mu \mathrm{M})$ or removal of extracellular $\mathrm{Ca}^{2+}$ for a $\mathbf{3 0}$ min window following agonist exposure failed to prevent the delayed $\mathrm{Ca}^{2+}$ overload. The delayed $\left[\mathrm{Ca}^{2+}\right]_{i}$ increase could be reversed by removing extracellular $\mathrm{Ca}^{2}{ }^{2}$, indicating that it resulted from $\mathrm{Ca}^{2+}$ influx. The three phases defined by changes in the $\left[\mathrm{Ca}^{2+}\right]$, during glutamate-induced neuronal toxicity suggest three distinct targets to which neuroprotective agents may be directed.

\footnotetext{
Received Aug. 5, 1991; revised Dec. 3, 1991; accepted Dec. 18, 1991.

This work was supported by grants from the NSF (BNS 9010486), the American Heart Association, the Joseph P. Kennedy Foundation, and ICI Americas, Inc.

Correspondence should be addressed to Dr. S. A. Thayer, Department of Pharmacology, University of Minnesota Medical School, 3-249 Millard Hall, 435 Delaware Street S.E., Minneapolis, MN 55455.

a Present address: Department of Neurology, VA Medical Center, Neurology (127), One Veteran Drive, Minneapolis, MN 55417.

Copyright (C) 1992 Society for Neuroscience $0270-6474 / 92 / 121882-14 \$ 05.00 / 0$
}

Excitatory amino acids (EAAs), in addition to their role in fast excitatory neurotransmission and synaptic plasticity, have been implicated in neurotoxicity. The idea that EAAs, specifically excess glutamate release, may mediate neuronal cell death was originally proposed by Olney (1978) as the "excitotoxicity hypothesis." It has been observed that glutamate receptor antagonists protect neurons from death produced by several acute neurodegenerative disorders including hypoxia/ischemia (Siesjö, 1981; Siesjö and Bengtsson, 1989), epilepsy (Köhr and Heinemann, 1989), and trauma (Faden et al., 1989). Excessive EAA accumulation may also underlie chronic neurodegenerative diseases including Huntington's disease (Young et al., 1988), Alzheimer's disease (Greenamyre et al., 1985), Parkinson's disease (Turski et al., 1991), and AIDS dementia (Giulian et al., 1990; Heyes et al., 1990). In vitro assays employing cultured neurons have shown that $\mathrm{Ca}^{2+}$ is an essential requirement for the development of glutamate neurotoxicity (Choi, 1987).

An uncontrolled and excessive accumulation of $\mathrm{Ca}^{2+}$ has been implicated as a unifying theme in a number of cytotoxic processes (Schanne et al., 1979). However, $\mathrm{Ca}^{2+}$ influx is clearly important for the normal physiological function served by EAA receptors (Collingridge and Bliss, 1987; Malenka et al., 1989). Several reports have shown that glutamatergic agonists will produce large $\left[\mathrm{Ca}^{2+}\right]_{i}$ transients that recover upon removal of the agonist, allowing multiple responses to be generated (Mayer et al., 1987; Ogura et al., 1988; Yustc and Katz, 1991). In contrast, other studies investigating the role of $\mathrm{Ca}^{2+}$ in glutamate-induced neurotoxicity have found that the $\left[\mathrm{Ca}^{2+}\right]_{i}$ remained elevated following sustained or repeated glutamate exposure (Connor et al., 1988; Manev et al., 1989; de Erausquin et al., 1990; Glaum et al., 1990). These reports suggest that glutamate produces a change in neuronal $\left[\mathrm{Ca}^{2+}\right]_{i}$ homeostasis, such as prolonged activation of a $\mathrm{Ca}^{21}$ conductance, from which neurons rarely recover.

Inconsistency in the literature concerning $\left[\mathrm{Ca}^{2+}\right]_{l}$ following removal of EAA receptor agonists invokes the question of whether a return to a basal $\left[\mathrm{Ca}^{2+}\right]_{i}$ level predicts a sparing from neurotoxicity. To produce delayed neurotoxicity, we have employed a paradigm used previously by Choi et al. (1987) in which rat hippocampal neurons were exposed to glutamate for $5 \mathrm{~min}$. $\left[\mathrm{Ca}^{2+}\right]_{i}$ was monitored for $3 \mathrm{hr}$ following glutamate exposure to determine a chronology of changes in $\left[\mathrm{Ca}^{2+}\right]_{i}$ that precede glutamate-induced delayed cell death.

\section{Materials and Methods}

Cell culture. Rat hippocampal neurons were grown in primary culture as described by Thayer et al. (1986) with minor modifications. Fetuses were removed on embryonic day 17 from maternal rats killed by de- 
A

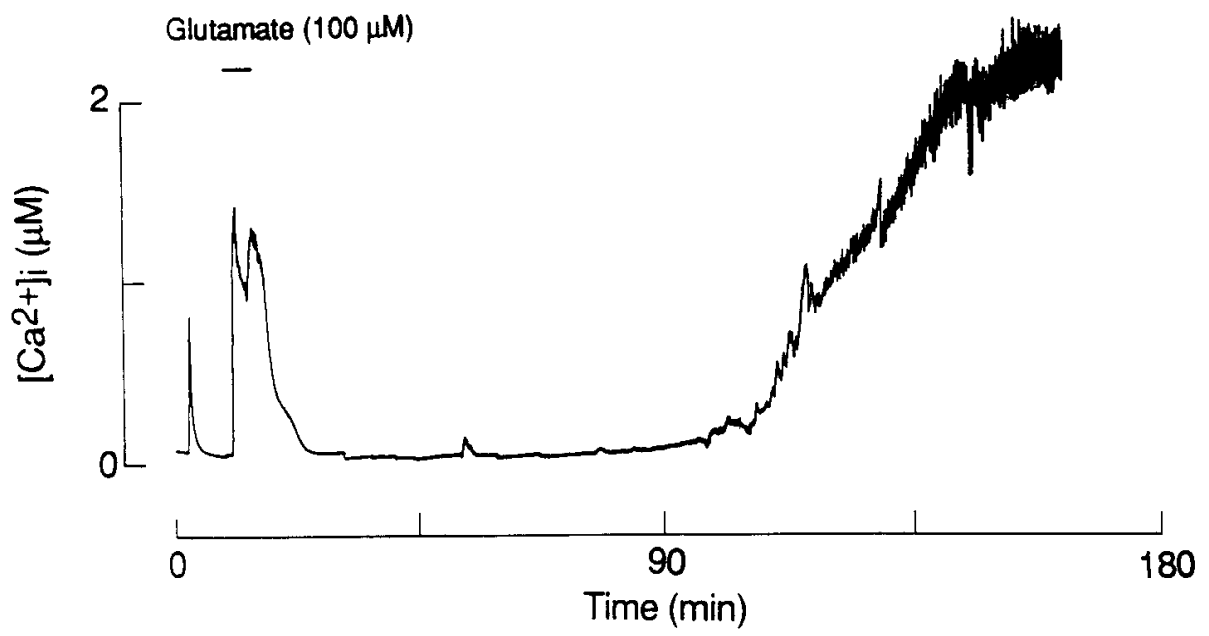

B

\begin{tabular}{|c|c|c|}
\hline $\begin{array}{l}\text { Trigger } \\
\text { (toxin exposure) }\end{array}$ & $\begin{array}{l}\text { Latent Period } \\
\text { (normal calcium) }\end{array}$ & $\begin{array}{c}\text { Calcium Overload } \\
\text { (delayed calcium increase) }\end{array}$ \\
\hline EDPa & & AII \\
\hline $0 \quad 5$ & $\mathrm{Tim}$ & $\begin{array}{l}120 \\
\text { approx.) }\end{array}$ \\
\hline
\end{tabular}

Figure 1. Time course of glutamateinduced $\mathrm{Ca}^{2+}$ overload. $A$, The $\left[\mathrm{Ca}^{2+}\right]$ in a single hippocampal neuron was measured by indo-1-based microfluorimetry as described in Materials and Methods. Glutamate $(100 \mu \mathrm{M})$ was superfused onto the cell during the time indicated by the short horizontal bar. This recording is representative of the delayed $\left[\mathrm{Ca}^{2+}\right]_{i}$ increase observed in $44 \%$ of the neurons challenged with glutamate. $B, A$ schematic representing the chronology of glutamate-induced $\left[\mathrm{Ca}^{2+}\right]_{i}$ changes and neurotoxicity. capitation. Hippocampi were dissected and placed in $\mathrm{Ca}^{2+} / \mathrm{Mg}^{2+}-$ free HEPES-buffered Hank's salt solution (CMF-HH) containing $0.1 \%$ trypsin for $20 \mathrm{~min}$ at $25^{\circ} \mathrm{C}$. $\mathrm{HH}$ was composed of the following (in $\mathrm{mM}$ ): HEPES, $20 ; \mathrm{NaCl}, 137 ; \mathrm{CaCl}_{2}, 1.3 ; \mathrm{MgSO}_{4}, 0.4 ; \mathrm{MgCl}_{2}, 0.5 ; \mathrm{KCl}, 5.0$; $\mathrm{KH}_{2} \mathrm{PO}_{4}, 0.4 ; \mathrm{NaHPO}_{4}, 0.6 ; \mathrm{NaHCO}_{3}, 3.0$; and glucose, 5.6. Trypsin was inactivated by the addition of fetal bovine serum (FBS). The cells were dissociated by trituration through a $5 \mathrm{ml}$ pipette and if tissue clumps remained, through a flame narrowed Pasteur pipette. The cells were pelleted and resuspended in Dulbeco's modified Eagle's medium (DMEM) supplemented with 10\% FBS. Dissociated cells were then plated at a density of 500,000 cells/well onto $25 \mathrm{~mm}$ round coverglasses (\#1) that had been coated with poly-D-lysine $(0.1 \mathrm{mg} / \mathrm{ml})$ and washed with CMF-HH. The neurons were grown in a humidified atmosphere of $8 \% \mathrm{CO}_{2}$ and $92 \%$ air (pH 7.4) at $37^{\circ} \mathrm{C}$ and fed every $4-5 \mathrm{~d}$ with DMEM $/ 10 \%$ horse serum. Cells employed for these experiments were grown in culture for a minimum of $10 \mathrm{~d}$, with all measurements made on single cells.

Instrumentation. $\left[\mathrm{Ca}^{2+}\right]_{i}$ was monitored in single cells using indo-1 and a dual-emission microfluorimeter. For excitation of indo-1, the light from a $75 \mathrm{~W} \mathrm{Xe} \mathrm{arc} \mathrm{lamp} \mathrm{was} \mathrm{passed} \mathrm{through} \mathrm{a} \mathrm{monochromator} \mathrm{(Photon}$ Technologies Inc.) set for $350 \mathrm{~nm}$ (slit width, $2 \mathrm{~nm}$ ) and collimated with a parabolic mirror. For epifluorescence excitation, light was reflected off a dichroic mirror ( $380 \mathrm{~nm}$; Omega Optical) and through a $70 \times$ phasecontrast oil-immersion objective (Leitz; NA 1.15). Emitted light was sequentially reflected off dichroic mirrors (440 and $516 \mathrm{~nm}$ ) through bandpass filters (405/20 and $495 / 20 \mathrm{~nm}$, respectively) to photomultiplier tuhes operating in photon counting mode (Thorn EMI). Cells were illuminated with transmitted light $(610 \mathrm{~nm}$ long pass) and visualized with a video camera placed after the second emission dichroic. $R e-$ cordings were defined spatially with a rectangular diaphragm that limited recordings to areas within single cells but did not resolve gradients within an individual cell. The TTL photomultiplier outputs were integrated by passing the signals through eight-pole Bessel filters at a cutoff frequency of $2.5 \mathrm{~Hz}$. These signals were then input to two channels of a direct memory access analog-to-digital converter (Indec Systems) continuously sampling at $200 \mathrm{~Hz}$. Data points were averaged every second resulting in a final sampling rate of $1 \mathrm{~Hz}$.
Calibration. After completion of an experiment, the microscope stage was adjusted so that no cells or debris occupied the field of view defined by the diaphragm, and background light levels were determined (typically less than $5 \%$ of cell counts). Autofluorescence from cells not loaded with indo-1 was undetectable. Records were later corrected for background and ratios recalculated. Ratios were converted to free $\left[\mathrm{Ca}^{2+}\right]_{i}$ by the equation $\left[\mathrm{Ca}^{2+}\right]_{i}=K \beta\left(R-R_{\min }\right) /\left(R_{\max }-R\right)$, in which $R$ is the $405 /$ $495 \mathrm{~nm}$ fluorescence emission ratio and $K=250 \mathrm{nM}$, the dissociation constant for indo-1 (Grynkiewicz et al., 1985). The maximum ratio $\left(R_{\max }\right)$, the minimum ratio $\left(R_{\min }\right)$, and the constant $\beta$ (the ratio of the fluorescence measured at 495 in the absence and presence of saturating $\mathrm{Ca}^{2+}$ ) were determined in neurons by treatment with $20 \mu \mathrm{M}$ ionomycin in the absence (1 mM EGTA) and presence of saturating $\mathrm{Ca}^{2+}(10 \mathrm{~mm}$ $\left(\mathrm{a}^{2+}\right)$. The system was recalibrated following any adjustment to the apparatus. Values for $R_{\min }, R_{\max }$, and $\beta$ were in the ranges of $0.41-0.44$, $4.32-4.48$, and $840-853$, respectively.

Experimental procedure. Neurons were incubated in $2-4 \mu \mathrm{M}$ of the acetoxymethyl ester form of indo- 1 in $\mathrm{HH}$ containing $0.5 \%$ bovine serum albumin for $45-60 \mathrm{~min}$ at $37^{\circ} \mathrm{C}$. During loading, the ester is hydrolyzed to the membrane-impermeant free acid form by cytosolic esterases. The coverglass was then mounted in a flow-through chamber (Thayer et al., 1988) and placed on the stage of the microfluorimeter. Loading was terminated by perfusion with $\mathrm{HH}$ for $20-30 \mathrm{~min}$ prior to starting an experiment. Experiments were run at room temperature. Basal $\left[\mathrm{Ca}^{2+}\right]_{i}$ was measured for $5 \mathrm{~min}$ prior to exposure to glutamate $(100 \mu \mathrm{M})$ for $5 \mathrm{~min}$, followed by continuous recording of $\left[\mathrm{Ca}^{2+}\right]_{i}$ for 3 $\mathrm{hr}$. The chamber was superfused at a rate of $2 \mathrm{ml} / \mathrm{min}$ during the first $15 \mathrm{~min}$ of the experiment, and then flow was stopped for the remainder of the experiment except to exchange buffer during drug or ion substitutions. Superfusion solutions were selected with a multiport valve coupled to several reservoirs. In the absence of superfusion, $\mathrm{HH}$ buffer covered the cells at a depth of about $8 \mathrm{~mm}$. All buffers used in this study containcd $10 \mu \mathrm{M}$ glycine. $\mathrm{CaCl}_{2}$ was replaced with $20 \mu \mathrm{M}$ EGTA for $\mathrm{Ca}^{2+}$-free experiments. Criteria used for selecting a neuron for study included phase-bright appearance, smooth soma, distinct processes, and loading of approximately $20 \mu \mathrm{M}$ indo- 1 as estimated by comparison of intensity values from in vitro standards. 


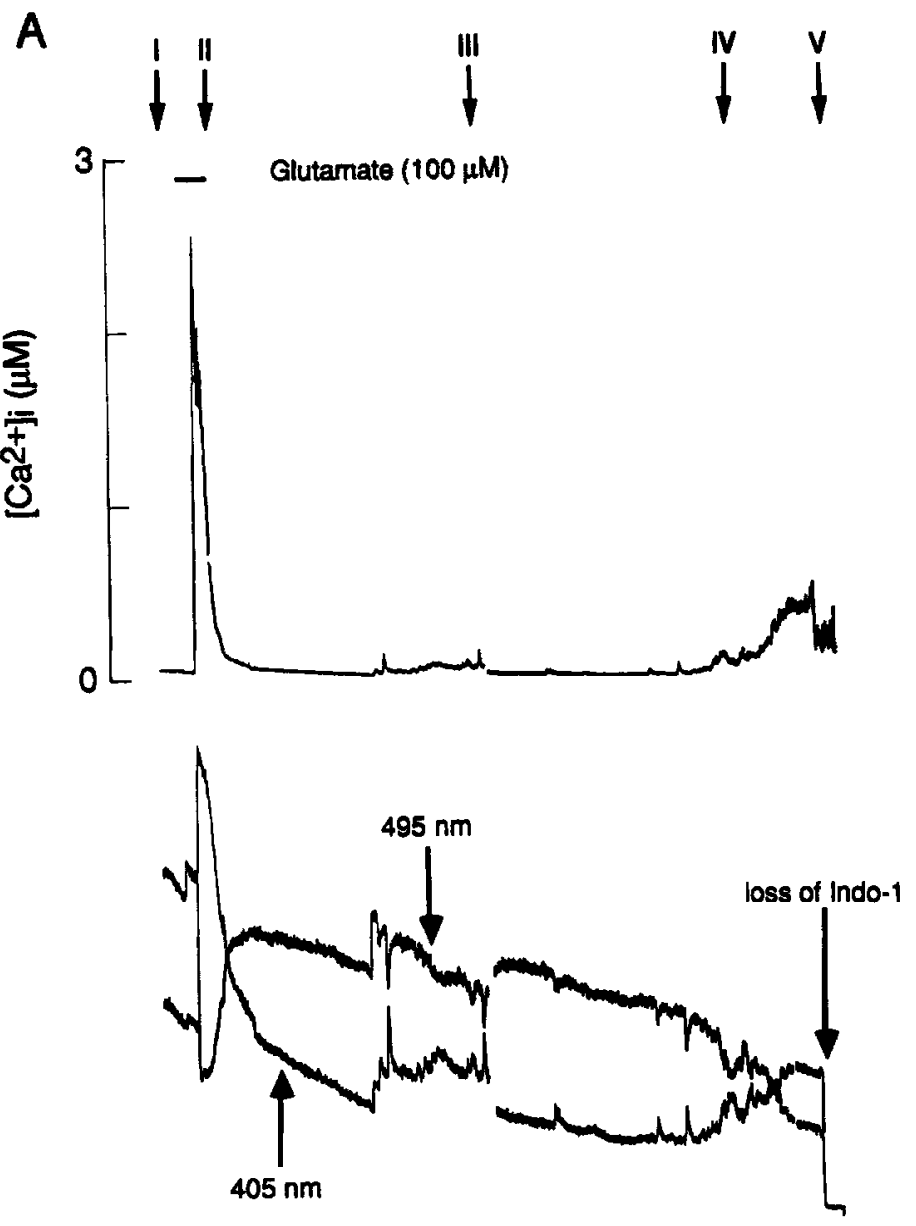

Figure 2. Glutamate-induced $\left[\mathrm{Ca}^{2+}\right]$ changes and neurotoxicity. $A$, Glutamate $(100 \mu \mathrm{M})$ was superfused onto the cell during the time indicated by the short horizontal bar. Changes in $\left[\mathrm{Ca}^{2+}\right]_{i}$ are shown above the corresponding unprocessed fluorescence intensity values ( $A$, bottom panel). Note the abrupt drop in fluorescence intensity to background levels at the end of the recording. $B, A$ control recording in which the neuron was not exposed to glutamate but handled identically in all other respects to the cell in $A$, demonstrating the stability of these $3 \mathrm{hr}$ experiments. $\left[\mathrm{Ca}^{2+}\right]_{i}$ was measured as described in Materials Methods. Photomicrographs, displayed in Figure 3, were taken at the times indicated by $I-V I I$.

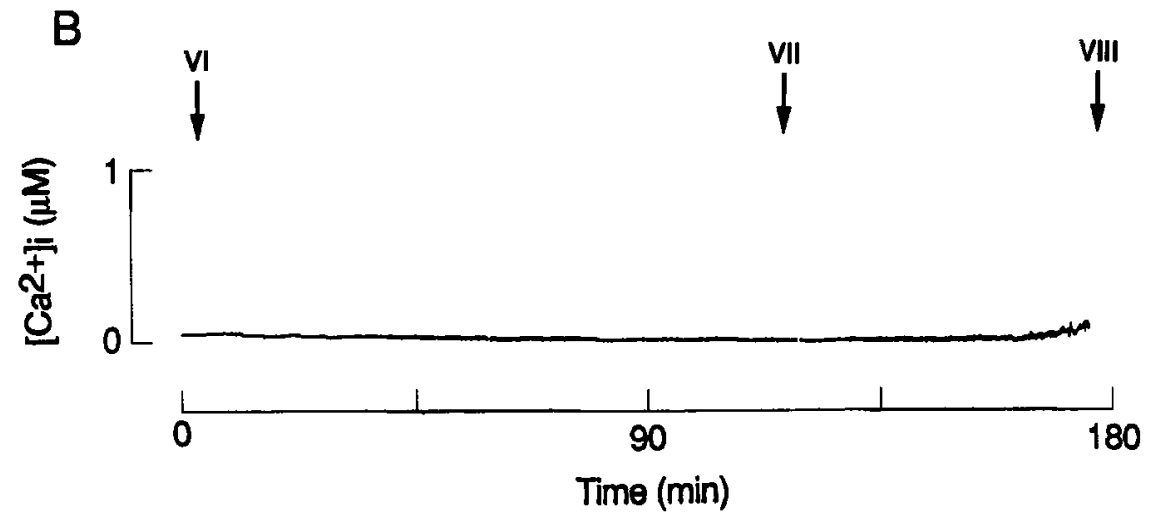

Data analysis. Data analysis was performed using ANOVA with Scheffe's and Dunnett's post hoc tests to determine significant differences in quantitative data and the $\chi^{2}$ test to determine significant differences in categorical data.

\section{Results}

\section{Chronology of glutamate-induced calcium overload}

Rat hippocampal neurons were grown in primary culture for a minimum of $10 \mathrm{~d}$, during which time they extended elaborate processes. Evidence of synaptic contact included visualization of interconnected cell processes with phase-contrast microscopy and frequent recording of spontaneous TTX and DL-2-amino5 -phosphonopentanoic acid (AP-5)-sensitive $\left[\mathrm{Ca}^{2+}\right]_{i}$ spiking activity. Cells were loaded with the $\mathrm{Ca}^{2+}$-sensitive dye indo- 1 and placed on the stage of a dual-emission microfluorimeter for measuring $\left[\mathrm{Ca}^{2+}\right]_{i}$ as described in Materials and Methods. When challenged with $100 \mu \mathrm{M}$ glutamate for $5 \mathrm{~min}$, virtually every neuron $(n=64)$ responded with a large increase in $\left[\mathrm{Ca}^{2+}\right]_{i}$, from $54 \pm 4 \mathrm{nM}$ to $2874 \pm 348 \mathrm{nM}$, and declined to $1712 \pm 270 \mathrm{nM}$ immediately prior to termination of the 5 min exposure. In 



Figure 3. Morphological changes observed in hippocampal neurons in the presence and absence of glutamate. A, Morphological changes in the hippocampal neuron treated with glutamate shown in Figure $2 A$ are displayed in the photomicrographs labeled $I-V$. B, Photomicrographs of the control $(V I-V I I I)$ neuron are shown for the times indicated in Figure $2 B$.

contrast to some reports in which EAA-induced $\left[\mathrm{Ca}^{2+}\right]_{i}$ transients were measured optically (Connor et al., 1988; de Erausquin et al., 1990; Glaum et al., 1990) but in agreement with others (MacDermott et al., 1986; Murphy et al., 1987; Ogura et al., 1988), we have observed complete recovery of the $\left[\mathrm{Ca}^{2+}\right]_{i}$ upon removal of glutamate (Fig. $1 A$ ) in $92 \%$ of treated neurons. Thus, the ability of neurons to regulate $\left[\mathrm{Ca}^{2+}\right]_{i}$ levels had not been compromised following removal of the EAAs. However, 

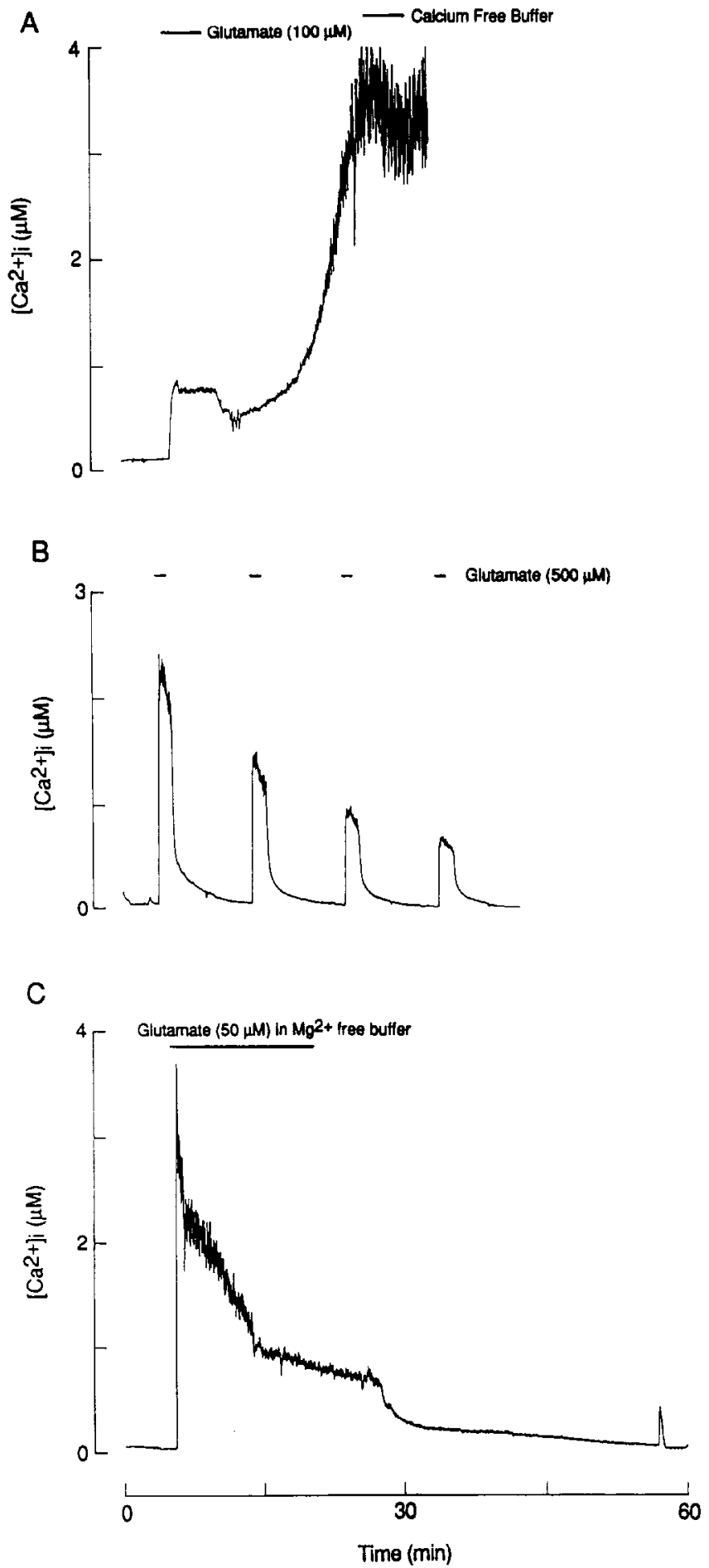

Figure 4. Glutamate-induced $\left[\mathrm{Ca}^{2+}\right]_{i}$ transients that elicit a sustained $\mathrm{Ca}^{2+}$ load arc not dependent on the glutamate treatment protocol. $\left[\mathrm{Ca}^{2+}\right]_{i}$ was measured as described in Materials and Methods. A, A representative recording showing one of the five $(n=64)$ cells that failed to recover from the $\left[\mathrm{Ca}^{2+}\right]_{i}$ transient elicited by $5 \mathrm{~min}$ exposure to $100 \mu \mathrm{M}$ glutamate. $B, A$ representative recording $(n=5)$ demonstrating that repetitive glutamate exposure does not necessarily produce a sustained $\left[\mathrm{Ca}^{2+}\right]_{i}$ increase. Glutamate at $500 \mu \mathrm{M}$ was applied to the cell during the times indicated by the short horizontal bars. $C$, A representative recording $(n=4)$ demonstrating that prolonged exposure to glutamate does not produce a sustained $\left[\mathrm{Ca}^{2+}\right]_{i}$ increase. Glutamate at $50 \mu \mathrm{M}$ was applied to the cell in $\mathrm{Mg}^{2+}$ free buffer for $15 \mathrm{~min}$ at the time indicated by the short horizontal bar. this initial $\left[\mathrm{Ca}^{2+}\right]_{i}$ transient served as a trigger for subsequent changes in $\left[\mathrm{Ca}^{2+}\right]_{i}$. In some cells, return to basal $\left[\mathrm{Ca}^{2+}\right]_{i}$ levels was interrupted by $\left[\mathrm{Ca}^{2+}\right]_{i}$ transients of variable frequency and amplitude. A latent destructive process induced by the increase in $\left[\mathrm{Ca}^{2+}\right]_{i}$ during glutamate exposure is apparently active during this period as indicated by a gradual increase in $\left[\mathrm{Ca}^{2+}\right]_{i}$ resulting in $\mathrm{Ca}^{2+}$ overload (Fig. 1A). A similar delayed increase in $\left[\mathrm{Ca}^{2+}\right]_{i}$ has been observed following hypoxia in reoxygenated cerebrocortical cell cultures (Marcoux et al., 1990). The delay between termination of glutamate exposure and the secondary $\left[\mathrm{Ca}^{2+}\right]_{i}$ increase was variable. Delayed $\mathrm{Ca}^{2+}$ overload was observed in $44 \%$ of neurons that buffered $\left[\mathrm{Ca}^{2+}\right]$, back to basal levels $(n=$ 59 ), as determined by a $\left[\mathrm{Ca}^{2+}\right]_{i}$ value that was at least twofold greater than the initial baseline. A twofold increase was a conservative criterion since the dynamic range of the indo-1 dccreased slightly following $3 \mathrm{hr}$ of continuous recording, due perhaps to uptake of the dye into intracellular compartments or conversion to $\mathrm{Ca}^{2+}$-insensitive form of the dye that retains fluorescence (Cobbold and Rink, 1987; Roe et al., 1990; Wahl et al., 1990). Cell death was defined as the sudden loss of the $\mathrm{Ca}^{2+}$ indicator dye, which was found to yield identical results to those obtained by measuring trypan blue uptake. Overall, $20 \%$ of the cells exposed to glutamate $(n=64)$ died during the $3 \mathrm{hr}$ recording and only cells that first exhibited $\mathrm{Ca}^{2+}$ overload died during the recording period. Five of 64 neurons examined did not buffer $\left[\mathrm{Ca}^{2+}\right]_{i}$ to basal values following glutamate washout but maintained a sustained iricrease in $\left[\mathrm{Ca}^{2+}\right]_{i}$ and subsequently died. A secondary $\left[\mathrm{Ca}^{2+}\right]_{i}$ increase was observed in 26 of the 59 cells that buffered the glutamate-induced $\mathrm{Ca}^{2+}$ load back to basal levels; $31 \%(n=8)$ of these neurons died during the $3 \mathrm{hr}$ recording period.

The time course of $\left[\mathrm{Ca}^{2+}\right]_{i}$ changes leading to neuronal death can be divided into three phases (Fig. 1B). The trigger phase is defined by the $5 \mathrm{~min}$ toxin exposure during which $\left[\mathrm{Ca}^{2+}\right]_{i}$ reached very high levels. This trigger was followed by a latent phase during which $\left[\mathrm{Ca}^{2+}\right]_{i}$ returned to basal levels and was occasionally interrupted by transient increases in $\left[\mathrm{Ca}^{2+}\right]_{i}$. The duration of this phase was variable ranging from 0 to greater than $3 \mathrm{hr}$. The latent phase was followed by a gradual increase in $\left[\mathrm{Ca}^{2+}\right]_{i}$ to a sustained plateau, which we have termed delayed $\mathrm{Ca}^{2+}$ overload. Neurons did not recover from the $\mathrm{Ca}^{2+}$ overload phase. In our experiments, the $\mathrm{Ca}^{2+}$ overload phase was terminated either by cell death or the end of a $3 \mathrm{hr}$ recording period.

Changes in cell morphology correlate with changes in the $\left[\mathrm{Ca}^{2+}\right]_{i}$. Representative experiments, shown in Figures 2 and 3, were performed on healthy hippocampal neurons as indicated by low resting $\left[\mathrm{Ca}^{2+}\right]_{i}$, phase-bright appearance, a smooth soma, and clearly defined processes (Figs. $2 A$ and $3 A, \mathrm{I} ; 2 B$ and $3 B$, VI). Glutamate $(100 \mu \mathrm{M})$ elicited a large increase in $\left[\mathrm{Ca}^{2+}\right]_{i}$ (approximately $2.1 \mu \mathrm{M}$ declining to $1.5 \mu \mathrm{M}$ ) that was accompanied by the appearance of phase-dark material in the soma (Figs. $2 \mathrm{~A}$ and $3 A$, II). Upon removal of glutamate, the $\left[\mathrm{Ca}^{2+}\right]_{i}$ returned to baseline and remained at resting levels for over $1 \mathrm{hr}$. This was followed by a gradual increase in $\left[\mathrm{Ca}^{2+}\right]_{i}$ accompanied by profound changes in morphology including retraction of processes, marked membrane blebbing, and eventually cell lysis (Figs. $2 A$ and $3 A, \mathrm{~V}$ ). Cell death was defined as loss of membrane integrity assessed by sudden loss of the membrane-impermeant $\mathrm{Ca}^{2+}$ indicator dye. Individual fluorescent intensity values for $\mathrm{Ca}^{2+}$-bound $(405 \mathrm{~nm})$ and $\mathrm{Ca}^{2+}$-unbound $(495 \mathrm{~nm})$ forms of indo- 1 are displayed in the lower panel of Figure $2 A$, with cell death indicated by abrupt loss of fluorescence at both emission 

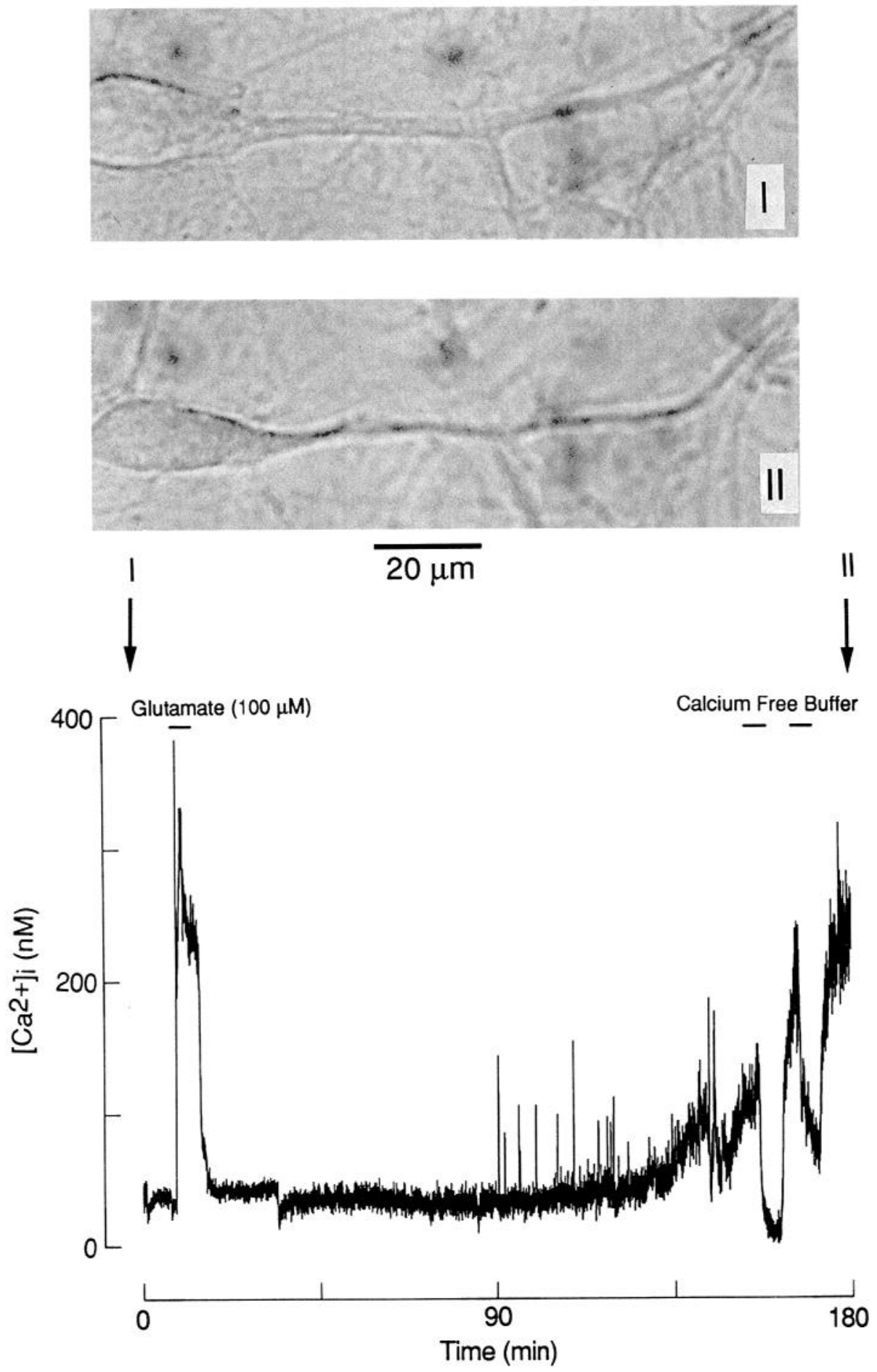

Figure 5. Glutamate induces delayed $\mathrm{Ca}^{2+}$ overload in neuronal processes. The $\left[\mathrm{Ca}^{2+}\right]$, was measured in a single process emanating from an identifiable hippocampal neuron. Glutamate or $\mathrm{Ca}^{2+}$-free buffer was superfused onto the cell during the times indicated by the short horizontal bars in the bottom panel. Photomicrographs of this cell were taken before the application of glutamate $(I)$ and after the delayed $\left[\mathrm{Ca}^{2+}\right]_{t}$ increase $(I I)$. wavelengths. Thirty-one percent of the cells that displayed a secondary $\left[\mathrm{Ca}^{2+}\right]_{i}$ increase subsequently died, suggesting that a secondary $\left[\mathrm{Ca}^{2+}\right]_{i}$ increase is a harbinger of cell death.

Neurons not treated with glutamate remained viable throughout the $3 \mathrm{hr}$ recording. The recording shown in Figure $2 B$ is representative of 16 control neurons taken from the same cultures used for glutamate exposures. The control cells were superfused for the same time period as the glutamate-treated cells. One of 16 cells showed a $\left[\mathrm{Ca}^{2+}\right]_{i}$ increase near the end of the recording period. In the remaining neurons, basal $\left[\mathrm{Ca}^{2+}\right]_{i}$ re- mained low throughout the $3 \mathrm{hr}$ recording. Some untreated cells displayed repetitive $\mathrm{Ca}^{2+}$ transients that we believe to be synaptic activity, but did not exhibit delayed $\mathrm{Ca}^{2+}$ overload. Control neurons did not show any of the gross morphological changes associated with neurotoxicity during the $3 \mathrm{hr}$ recording period (Fig. 3B, VI-VIII). Thus, cell viability was maintained under the experimental conditions employed here, indicating that neither excitation with ultraviolet light nor molecular changes in the indicator dye elicited toxicity during the course of an experiment. We attribute the lack of toxicity in control neurons 
Figure 6. Extracellular $\mathrm{Ca}^{2+}$ is required during the trigger phase to elicit the delayed $\left[\mathrm{Ca}^{2+}\right]_{i}$ increase. The $\left[\mathrm{Ca}^{2+}\right]_{i}$ was measured as described in Materials and Methods. Extracellular $\mathrm{Ca}^{2+}$ was removed prior to and during the $5 \mathrm{~min}$ glutamate exposure as indicated by the horizontal bars. The two recordings are representative of 10 replicates and show experiments run on spontaneously active $(A)$ and quiescent $(B)$ neurons.
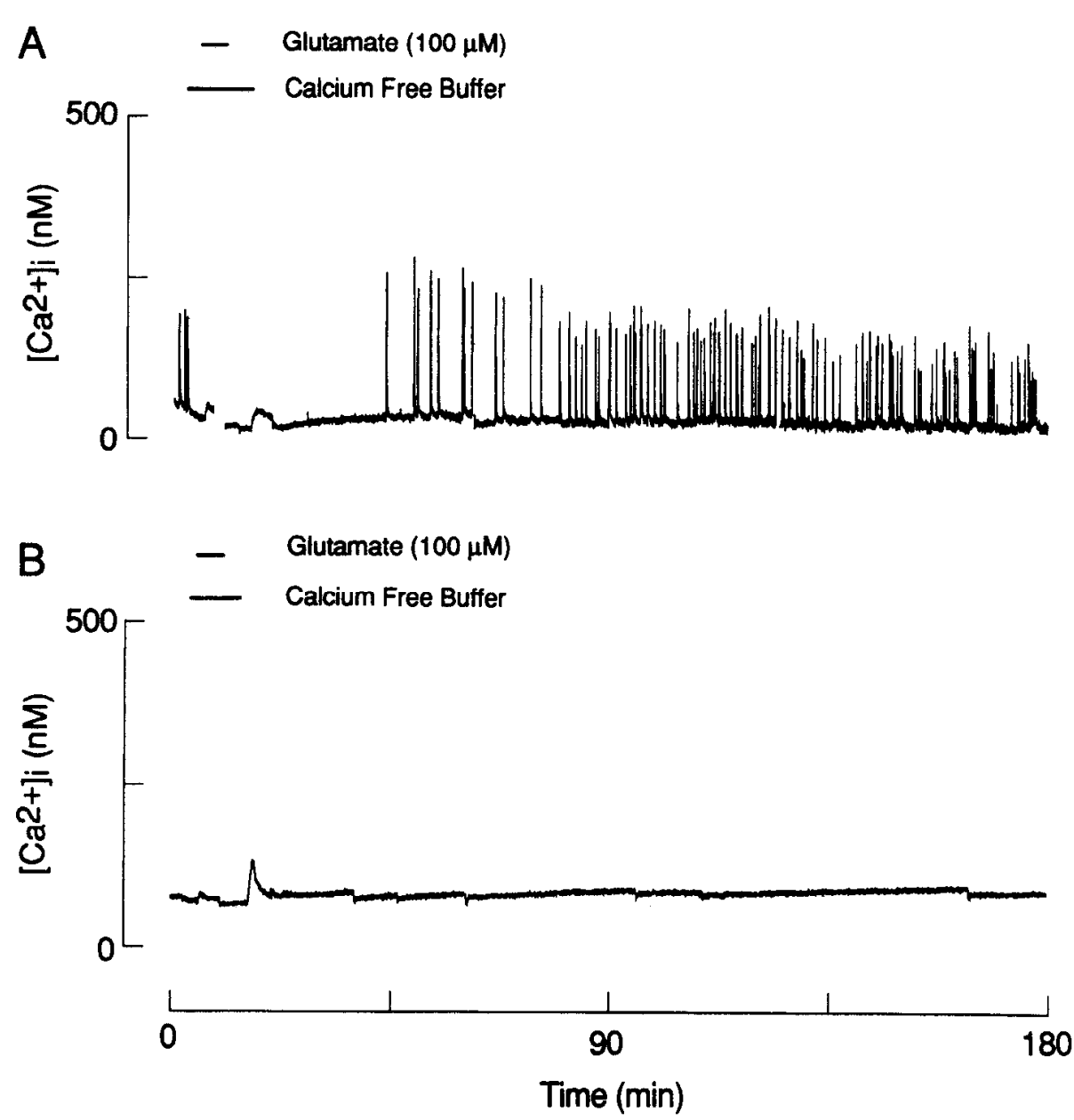

to the low intensity of excitation light as indicated by the slow loss of indicator associated with extrusion and bleaching shown in the Figure $2 A$ intensity plots.

The $5 \mathrm{~min}$ exposure to $100 \mu \mathrm{M}$ glutamate employed in these studies has been used extensively in the study of the $\mathrm{Ca}^{2+}$ dependent delayed neurotoxicity produced by EAAs. The time course for the glutamate-induced changes in $\left[\mathrm{Ca}^{2+}\right]_{i}$ described here differs in some respects to results described by others. Five of 64 neurons examined did not buffer $\left[\mathrm{Ca}^{2+}\right]_{i}$ to basal values following glutamate washout, but maintained a sustained increase in $\left[\mathrm{Ca}^{2+}\right]_{i}$ and subsequently died (Fig. $4 A$ ). This finding concurs with reports that described a sustained elevation in $\left[\mathrm{Ca}^{2+}\right]_{i}$ following glutamate exposure (Manev et al., 1989; de Erausquin et al., 1990; Glaum et al., 1990), although a smaller percentage of neurons exhibited this phenomenon in our studies. We explored the possibility that differences in the duration of exposure, presence of $\mathrm{Mg}^{2+}$, and use of repetitive EAA exposures may account for this discrepancy. Repeated application of glutamate failed to produce sustained $\left[\mathrm{Ca}^{2+}\right]_{i}$ increases in our hands $(n=5)$ in contrast to the observations of Glaum et al. (1990) (Fig. $4 B$ ). Similarly, the $\left[\mathrm{Ca}^{2+}\right]_{i}$ increase elicited by the $15 \mathrm{~min}$ glutamate exposure in $\mathbf{M g}^{2+}$-free media used by Manev et al. (1989) failed to elicit a sustained $\mathrm{Ca}^{2+}$ overload $(n=4)$. However, longer recovery times were required than those following a $5 \mathrm{~min}$ exposure to glutamate (Fig. 4C). Our mixed neuron hippocampal cultures differ from the hippocampal pyramidal cell and cerebellar granule cell cultures employed in these other studies. Differences in the sensitivity of hippocampal neuron types to glutamate toxicity has been reported (Mattson and $\mathrm{Ka}$ ter, 1989), as have differences in the sensitivity of hippocampal versus cerebellar cultures to NMDA toxicity (Garthwaite and Garthwaite, 1990). The density of astrocytes in the cultures may account for the differential sensitivity to glutamate observed in these various preparations (Rosenberg and Aizenman, 1989).

Connor et al. (1988) have shown that multiple focal applications of glutamate or NMDA to processes of hippocampal neurons will produce a standing $\left[\mathrm{Ca}^{2+}\right]_{i}$ gradient. It was of interest to determine whether the time course of glutamate-induced neurotoxicity observed in cell somata was applicable to $\left[\mathrm{Ca}^{2+}\right]_{i}$ changes recorded from processes. Consistent with our observations in the soma, processes of hippocampal neurons also displayed trigger, latent, and $\mathrm{Ca}^{2+}$ overload phases. Photographs of a process illustrate damage that includes process erosion and membrane fragmentation consistent with the glutamate-induced damage observed in the soma (Fig. 5). We have charactcrizcd the three phases of $\left[\mathrm{Ca}^{2+}\right]_{i}$ changes in more detail.

\section{The trigger phase}

The secondary $\left[\mathrm{Ca}^{2+}\right]_{i}$ increase was only observed if extracellular $\mathrm{Ca}^{2+}$ was present during glutamate exposure as shown in Figure 6 . Ten cells were challenged with $100 \mu \mathrm{M}$ glutamate in $\mathrm{Ca}^{2+}$ free medium; none of these cells displayed a secondary increase in $\left[\mathrm{Ca}^{2+}\right]_{i}$ and none of them died. Some cells displayed a small $(<100 \mathrm{nM})\left[\mathrm{Ca}^{2+}\right]_{i}$ increase upon readdition of $\mathrm{Ca}^{2+}$ to the media 

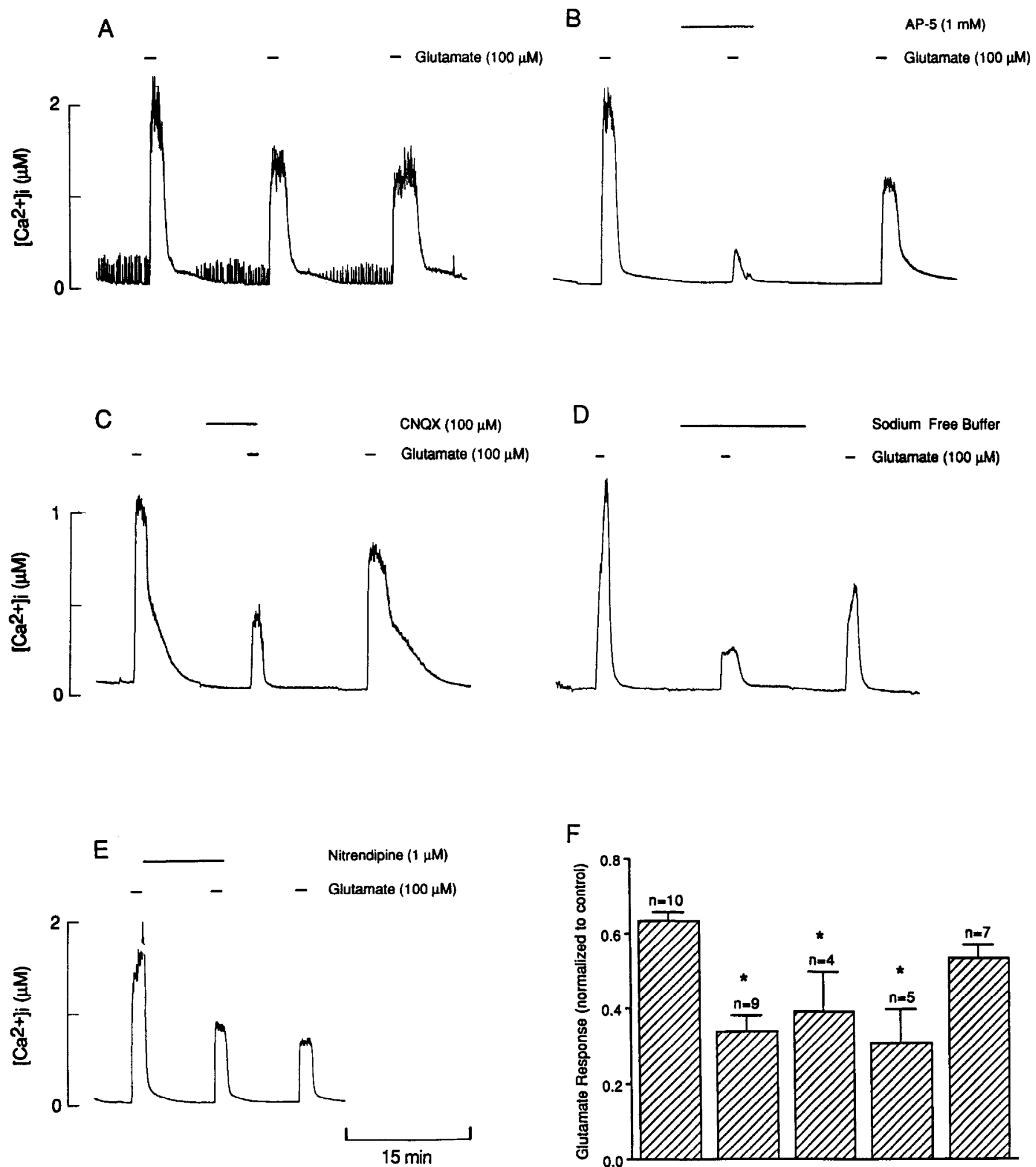

$\mathrm{F}$

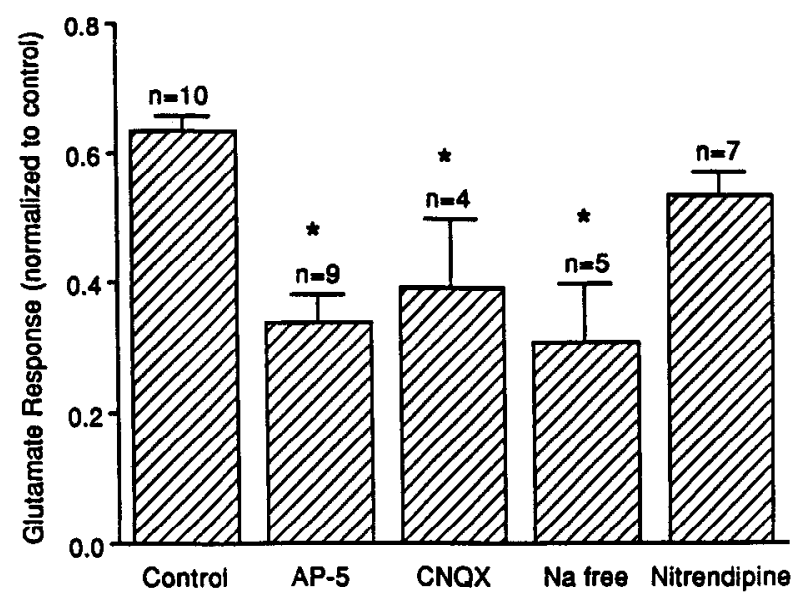

Figure 7. Pharmacological characterization of the glutamate-induced $\left[\mathrm{Ca}^{2+}\right]_{i}$ trigger. Glutamate at $100 \mu \mathrm{M}$ was superfused onto single hippocampal neurons for $30 \mathrm{sec}$ as indicated by the horizontal bars in $A-E$. The second response was elicited in the absence $(A)$ or presence of 1 mM AP-5 $(B)$, $100 \mu \mathrm{M}$ CNQX $(C), \mathrm{Na}^{+}$-free $(D)$, or $1 \mu \mathrm{M}$ nitrendipine $(E)$. Treatments were applied 5-10 min prior to eliciting the response as indicated by the horizontal bars. $F$, The effects of the various antagonists on glutamate-induced $\left[\mathrm{Ca}^{2+}\right]_{i}$ increases are summarized. The columns represent the mean \pm SE of the replicates expressed as a fraction of the initial control response. ${ }^{*}$, Significantly different from control $(p<0.05)$. 
(Fig. 6B), but this modest rebound was not sufficient to produce cell death. The $\mathrm{Ca}^{2+}$ dependence described here is similar to reports demonstrating a requirement for extracellular $\mathrm{Ca}^{2+}$ in delayed cell death (Garthwaite et al., 1986; Choi, 1987). Comparison of Figure $6 A$ with Figure $6 B$ indicates that even in neurons with spontaneous $\mathrm{Ca}^{2+}$ transients, the glutamate-induced $\mathrm{Ca}^{2+}$ influx was required to trigger events leading to delayed $\mathrm{Ca}^{2+}$ overload. There was not a significant correlation between the amplitude of the initial $\left[\mathrm{Ca}^{2+}\right]_{i}$ transient and the subsequent fate of the cell, perhaps due to difficulty using a highaffinity $\mathrm{Ca}^{2+}$ indicator such as indo- 1 to measure large transients such as those elicited by $100 \mu \mathrm{M}$ glutamate (Grynkiewicz et al., 1985; Ogura et al., 1988). Alternatively, the $\left[\mathrm{Ca}^{2+}\right]_{i}$ may simply need to cross a threshold level to produce delayed toxicity and that level was exceeded by all of the cells challenged with 100 $\mu \mathrm{M}$ glutamate. Although we were unable to correlate the amplitude of the initial $\left[\mathrm{Ca}^{2+}\right]_{i}$ transient with the subsequent fate of the cell, the influx of calcium during glutamate exposure was absolutely necessary to elicit the delayed increase in $\left[\mathrm{Ca}^{2+}\right]_{i}$ and neuronal death. Fifty-nine cells buffered $\left[\mathrm{Ca}^{2+}\right]_{i}$ back to basal levels after a glutamate challenge in the presence of extracellular $\mathrm{Ca}^{2+}$, of which 26 cells showed a secondary $\left[\mathrm{Ca}^{2+}\right]_{i}$ increase. In contrast, secondary $\left[\mathrm{Ca}^{2+}\right]_{i}$ increases were not observed when glutamate was applied in $\mathrm{Ca}^{2+}$-free medium $(n=10)$. Thus, the secondary increase in $\left[\mathrm{Ca}^{2+}\right]_{i}$ correlated significantly with an increase in $\left[\mathrm{Ca}^{2+}\right]_{i}$ during the trigger phase $(p<0.001)$. Every cell death observed (13 of 64) was preceded by an $\left[\mathrm{Ca}^{2+}\right]_{i}$ increase at least twofold above basal levels, indicating that cell death was significantly correlated with the $\left[\mathrm{Ca}^{2+}\right]_{i}$ increase that preceded it $(p<0.05)$. A larger percentage of neuronal death has been obscrved in neurotoxicity assays performed $24 \mathrm{hr}$ following glutamate exposure (Choi et al., 1987; Hartley and Choi, 1989; Manev et al., 1989; Mattson and Kater, 1989; Glaum et al., 1990).

Glutamate activates all EAA receptor subtypes. To determine the route of $\mathrm{Ca}^{2+}$ entry during the trigger phase, we treated cells with several brief $(60 \mathrm{sec})$ exposures to $100 \mu \mathrm{M}$ glutamate before and after various additions or ionic substitutions to the superfusing buffer. Repetitive application of glutamate elicited responses of steadily decreasing amplitude (Fig. $7 A ; n=10$ ). Response amplitude was expressed as a percentage of an initial control response, and statistical differences were determined between these values and those found in control neurons, as shown in Figure $7 F$. The competitive NMDA receptor antagonist AP-5 ( $1 \mathrm{mM} ; n=9$ ) produced a $46 \%$ inhibition (Fig. $7 B, F$ ) of the glutamate-induced $\left[\mathrm{Ca}^{2+}\right]_{i}$ transient $(n=10)$. Therefore, $100 \mu \mathrm{M}$ glutamate produces a sizeable influx of $\mathrm{Ca}^{2+}$ via the NMDA-gated ion channel in the presence of $\mathrm{Mg}^{2+}$, which is consistent with other reports (Yuste and Katz, 1991). The competitive non-NMDA receptor antagonist 6-cyano-7-nitroquinoxaline-2,3-dione (CNQX) (100 $\mu \mathrm{M} ; n=4)$ decreased the amplitude of the response by $38 \%$, consistent with a role for non-NMDA receptors in eliciting an increase in $\left[\mathrm{Ca}^{2+}\right]_{i}$ as well (Fig. 7C,F). However, at a concentration of $100 \mu \mathrm{M}, \mathrm{CNQX}$ may no longer be selective for non-NMDA receptor subtypes (Kleckner and Dingledine, 1989; Pellegrini-Giampietro et al., 1989). A lower concentration of CNQX $(10 \mu \mathrm{M})$ did not significantly inhibit $100 \mu \mathrm{M}$ glutamate-induced responses $(n=6)$ in the presence of $1 \mathrm{mM}$ AP-5. Competitive glutamate receptor antagonists are problematic for determining the fractional contribution of receptor subtypes to $\mathrm{Ca}^{2+}$ influx in the presence of a high concentration of glutamate as described here. The $\alpha$-amino-3-hy- droxy-5-methylisoxazole-4-propionic acid (AMPA)/kainate receptors are primarily permeable to monovalent cations (Collingridge and Lester, 1989; Hollmann et al., 1991) so that replacing extracellular $\mathrm{Na}^{+}$with the impermeant cation $N$-methyl-D-glucamine effectively blocks the depolarization induced by activation of these receptors. Removing extracellular $\mathrm{Na}^{+}$reduced the amplitude of the response by $71 \%$ (Fig. 7D,F). Depolarization resulting from influx of $\mathrm{Na}^{+}$via AMPA/kainatcgated channels could recruit voltage-sensitive $\mathrm{Ca}^{2+}$ channels, augmenting the NMDA-mediated $\mathrm{Ca}^{2+}$ influx. However, the voltage-sensitive $\mathrm{Ca}^{2+}$ channel blocker nitrendipine $(1 \mu \mathrm{M})$ produced only a $16 \%$ inhibition of the response to glutamate (Fig. $7 E, F)$ as in cerebellar neurons where glutamate-induced $\mathrm{Ca}^{2+}$ influx was not attenuated by nifedipine (de Erausquin et al., 1990). Recruitment of dihydropyridine-insensitive $\mathrm{Ca}^{2}$ channels would not be detected in these studies. In summary, we hypothesize that in response to $100 \mu \mathrm{M}$ glutamate the majority of the $\mathrm{Ca}^{2+}$ enters via the NMDA channels and non-NMDA channels serve primarily to relieve the voltage-dependent block of the NMDA-gated channel by $\mathrm{Mg}^{2+}$. This initial $\left[\mathrm{Ca}^{2+}\right]_{i}$ increase sets in motion events that subsequently lead to delayed $\mathrm{Ca}^{2+}$ overload and neuronal death.

\section{The latent phase}

Following the glutamate-induced $\left[\mathrm{Ca}^{2+}\right]_{i}$ transient and prior to the delayed $\mathrm{Ca}^{2+}$ overload, a period of basal $\left[\mathrm{Ca}^{2+}\right]_{i}$ was observed, which we term the latent period. Fifty-nine of 64 cells buffered $\mathrm{Ca}^{2+}$ back to basal levels following removal of glutamate; of these cells, 26 displayed a secondary increase in $\left[\mathrm{Ca}^{2+}\right]_{i}$ During the latent period, neurons typically had normal low resting $\left[\mathrm{Ca}^{2+}\right]_{i}$ and only a slight increase in the frequency of rapid $\mathrm{Ca}^{2+}$ transients distinguished a cell in this phase from an untreated cell. These spikes were completely abolished by $1 \mu \mathrm{M}$ TTX $(n=4)$, but inhibition of the spikes did not protect the cell from subsequent delayed $\mathrm{Ca}^{2+}$ overload (Fig. $8 \mathrm{~A}$ ). This finding is consistent with other reports that found that TTX does not prevent EAA-induced delayed cell death (Rothman, 1985; Choi et al., 1988; Peterson et al., 1989). Removal of extracellular $\mathrm{Ca}^{2+}$ for the first $30 \mathrm{~min}$ of this phase, a treatment found to be neuroprotective by some investigators (Hartley and Choi, 1989; Manev et al., 1989) also failed to prevent the delayed increase in $\left[\mathrm{Ca}^{2+}\right]_{i}$ (Fig. $8 B$ ). This finding is consistent with the low resting $\left[\mathrm{Ca}^{2+}\right]_{i}$ we observed in the latent phase of $92 \%$ of the neurons in this study.

\section{$\mathrm{Ca}^{2+}$ overload}

Forty-four percent (26 of 59) of hippocampal neurons exposed to $100 \mu \mathrm{M}$ glutamate displayed a secondary increase in $\left[\mathrm{Ca}^{2+}\right]_{i}$ during our $3 \mathrm{hr}$ recording period (see Figs. 1, 2, 8). Of those cells in which the secondary $\left[\mathrm{Ca}^{2+}\right]_{i}$ increase was observed, $31 \%$ ( 8 of 26) subsequently died as indicated by loss of the fluorescent indicator. Figure 9 shows the delayed $\mathrm{Ca}^{2+}$ overload portion of several records. The secondary $\left[\mathrm{Ca}^{2+}\right]_{i}$ increase probably resulted from $\mathrm{Ca}^{2+}$ influx and not intracellular release as indicated by reversal of the sustained elevation in $\left[\mathrm{Ca}^{2+}\right]_{i}$ when extracellular $\mathrm{Ca}^{2+}$ was removed, although the rate of decrease varied among the neurons examined. In Figure $9 A$, removing extracellular $\mathrm{Ca}^{2+}$ resulted in a rapid decrease in $\left[\mathrm{Ca}^{2+}\right]_{i}$ to a value less than resting levels. Calcium buffering and efflux mechanisms in this neuron responded quickly to the decreased $\mathrm{Ca}^{2+}$ influx. This was not always the case; in Figure $9 B$ a recording is shown in which $\left[\mathrm{Ca}^{2+}\right]_{i}$ decreased slowly and did not com- 
A

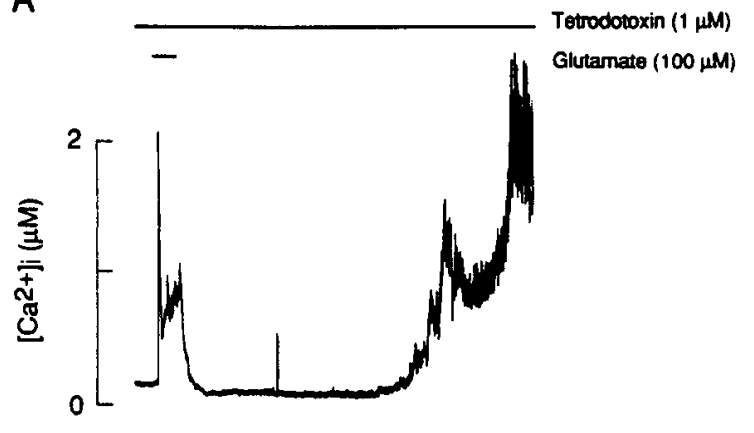

B

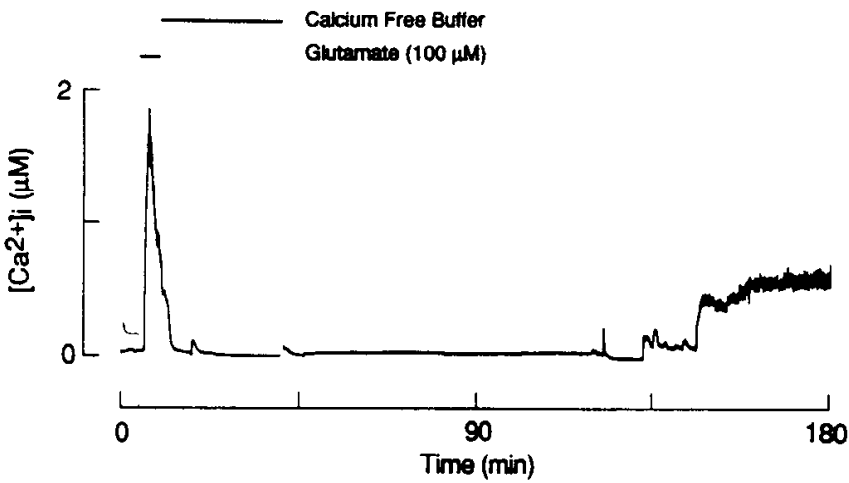

Figure 8. Synaptic activity and $\mathrm{Ca}^{2+}$ influx during the latent phase are not required for manifestation of delayed $\mathrm{Ca}^{2+}$ overload. $\left[\mathrm{Ca}^{2+}\right]_{i}$ was measured as described in Materials and Methods. Neurons were superfused with $100 \mu \mathrm{M}$ glutamate during the times indicated by the horizontal bars. In the record shown in $A$, the entire experiment was performed in the presence of $1 \mu \mathrm{M} \operatorname{TTX}(n=4)$. In $B$, extracellular $\mathrm{Ca}^{2+}$ was removed for $30 \mathrm{~min}$ following glutamate exposurc as indicated by the horizontal bars $(n=8)$.

pletely return to a basal level, suggesting that $\mathrm{Ca}^{2+}$ buffering and efflux mechanisms had been compromised. We observed similar results in recordings from neuronal processes (see Fig. 5). Note that reapplication of $\mathrm{Ca}^{2+}$ produced a rapid increase in the $\left[\mathrm{Ca}^{2+}\right]_{l}$ in each of these recordings, indicating an increased permeability to $\mathrm{Ca}^{2+}$. Although permeability to $\mathrm{Ca}^{2+}$ had increased, indicator dye had not leaked from these cells, indicating the plasma membrane was intact. Removal of extracellular $\mathrm{Ca}^{2+}$ reversed the sustained $\left[\mathrm{Ca}^{2+}\right]$ increase more rapidly, when removed immediately following the onset of the delayed rise in $\left[\mathrm{Ca}^{2+}\right]_{i}$ but was less effective after the $\left[\mathrm{Ca}^{2+}\right]_{i}$ had been elevatcd for scvcral minutes (Fig. 9C). This suggests that the ability to pump $\mathrm{Ca}^{2+}$ out of the cytoplasm may be compromised following a prolonged period of elevated $\left[\mathrm{Ca}^{2+}\right]_{i}$. The delayed $\mathrm{Ca}^{2+}$ influx was not reversed by the voltage-sensitive $\mathrm{Ca}^{2+}$ channel blocker nitrendipine $(10 \mu \mathrm{M} ; n=4)$, as shown in Figure $9 C$. A similar observation in cultured cerebellar cells suggests that dihydropyridine-sensitive $\mathrm{Ca}^{2+}$ channels are not responsible for maintaining the sustained $\mathrm{Ca}^{2+}$ influx following glutamate exposure (de Erausquin et al., 1990).

\section{Discussion}

We monitored the $\left[\mathrm{Ca}^{2+}\right]_{i}$ in single hippocampal neurons for 3 hr following a 5 min glutamate exposure. Observed changes in $\left[\mathrm{Ca}^{2+}\right]_{i}$ recorded in cell somata and processes followed a pattern that could be divided into three phases. During the first phase,
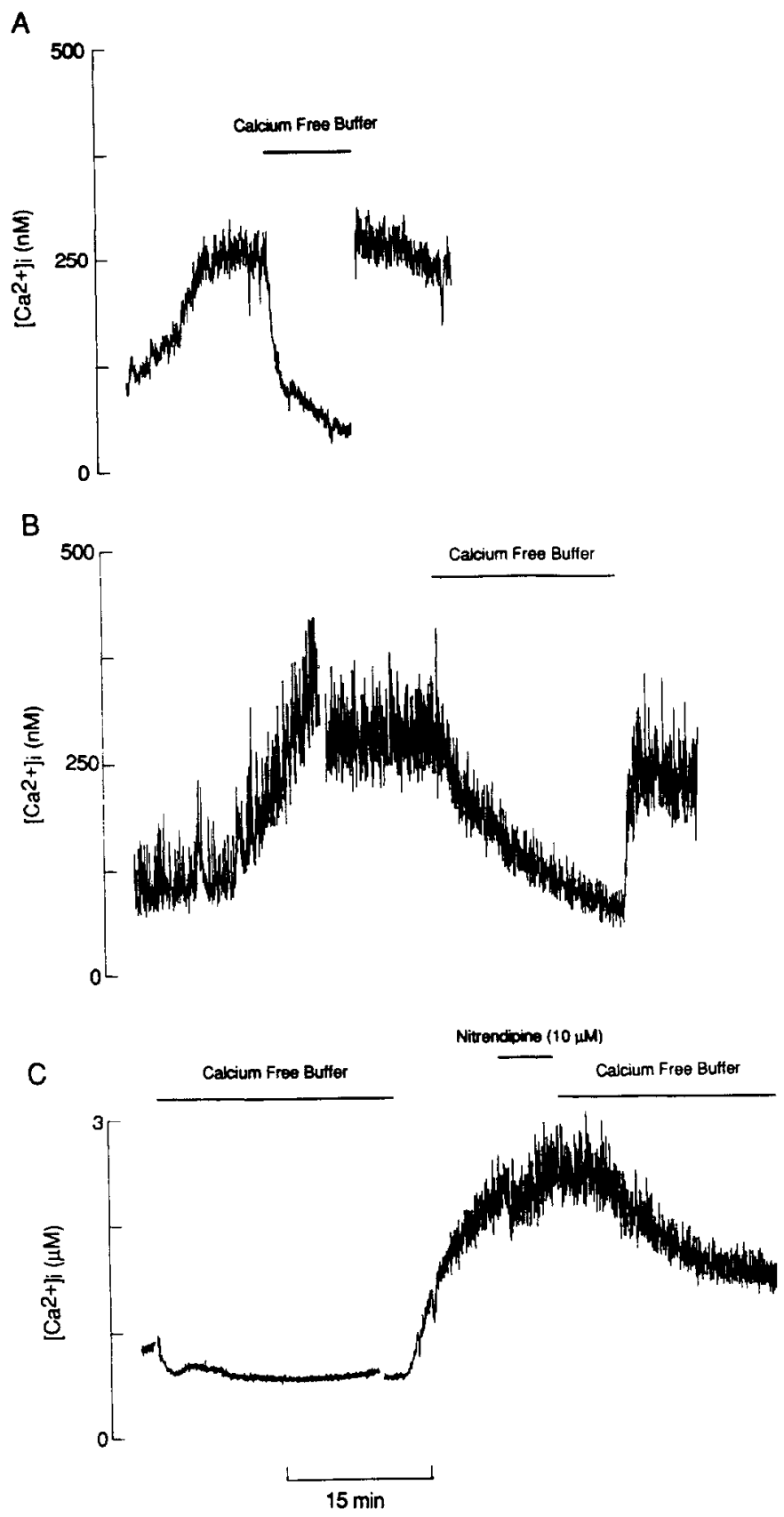

Figure 9. $\mathrm{Ca}^{2+}$ influx and buffering during the $\mathrm{Ca}^{2+}$ overload phase. $A-C$, The $\mathrm{Ca}^{2+}$ overload portion of records from three cells previously exposed to $100 \mu \mathrm{M}$ glutamate for $5 \mathrm{~min}$ are shown. Extracellular $\mathrm{Ca}^{2+}$ was removed or $10 \mu \mathrm{M}$ nitrendipine added at the times indicated by the horizontal bars.

glutamate exposure produced a large influx of $\mathrm{Ca}^{2+}$ in every cell $(n=64)$, which triggered a process leading to subsequent $\left[\mathrm{Ca}^{2+}\right]_{i}$ changes and neuronal death. The $\left[\mathrm{Ca}^{2+}\right]_{i}$ then recovered to basal levels (59 of 64 cells), indicating that elevated $\left[\mathrm{Ca}^{2+}\right]_{i}$ was not necessary to sustain the toxic processes latent during the second phase. The third phase was marked by an elevation in the $\left[\mathrm{Ca}^{2+}\right]_{i}$ (26 of 59) to a plateau level from which neurons did not recover. Neurons that died during our recording period (13 of 64) always displayed $\mathrm{Ca}^{2+}$ overload prior to death.

Choi has previously proposed a sequential three stage model describing glutamate neurotoxicity in vivo (Choi, 1990a,b). The 
chronology we describe here differs from Choi's model by focusing on events occurring within a single neuron. The principal finding of this study is the occurrence of a latent phase following EAA exposure. During this period, resting $\left[\mathrm{Ca}^{2+}\right]_{i}$ belies toxic mechanisms later manifested as a delayed $\mathrm{Ca}^{2+}$ overload. This result was anticipated by the work of Rothman et al. (1987), who observed only partial attenuation of delayed EAA toxicity in cultured hippocampal neurons by application of NMDA antagonists immediately after the removal of the EAA agonist. Thus, the $\mathrm{Ca}^{2+}$ load during EAA exposure had initiated delayed toxicity that was not mediated by the subsequent release of EAA. The requirement for $\mathrm{Ca}^{2+}$ during glutamate exposure in order to trigger, after some delay, $\mathrm{Ca}^{2+}$ overload and cell death suggests that the phenomena described here are early events in the process termed delayed neurotoxicity by others (Choi, 1987; Garthwaite and Garthwaite, 1990). However, certain aspects of our recording technique limit the duration of our studies to $3 \mathrm{hr}$, much shorter than the 18-24 hr time period allowed for development of "delayed" neurotoxicity. We believe that the relatively low number of cells that died during our recordings (13 of 64) is consistent with the early stages of a process that will develop into essentially total cell death when observed after 24 hr. Alternatively, our observations may indicate the presence of a glutamate-induced, $\mathrm{Ca}^{2+}$-dependent, short-term death.

Elevation of the $\left[\mathrm{Ca}^{2+}\right]_{i}$ during glutamate exposure acted as a trigger for delayed $\left[\mathrm{Ca}^{2+}\right]_{i}$ increase and toxicity. Evidence supporting this conclusion was first presented by Choi (1987) and confirmed by our experiments as shown in Figure 6 . Others have found that the amplitude of the initial $\left[\mathrm{Ca}^{2+}\right]_{i}$ transient was correlated with the number of cells that subsequently died (Milani et al., 1991). Five min exposure to $100 \mu \mathrm{M}$ glutamate produced a mean peak $\left[\mathrm{Ca}^{2+}\right]_{i}$ increase of $2.9 \mu \mathrm{M}$, which was considerably larger and far longer than that elicited by physiological stimuli. For example, note the small, rapid $\left[\mathrm{Ca}^{2+}\right]_{i}$ transients shown in Figure 6. In other cells exhibiting this kind of spontaneous firing, AP-5 (1 mM) completely blocked the spontaneous $\left[\mathrm{Ca}^{2+}\right]_{i}$ transients. This suggests that endogenous EAAs are released within the cultures and mediate the opening of synaptic NMDA-gated channels. These small and transient $\left[\mathrm{Ca}^{2+}\right]_{i}$ spikes were not neurotoxic. In a few neurons, a $5 \mathrm{~min}$ exposure to $100 \mu \mathrm{M}$ glutamate resulted in a $\mathrm{Ca}^{2+}$ load only twice the amplitude of these spontaneous transients, yet induced delayed toxicity. The duration of exposure to a continuous calcium load was greater during pathological exposure to glutamate than during spontaneous transients of similar amplitude and may be more important than the relative size of $\mathrm{Ca}^{2+}$ loads (Garthwaite and Garthwaite, 1990).

The idea that $\mathrm{Ca}^{2+}$ influx initiates toxicity independent of the route of $\mathrm{Ca}^{2+}$ entry is supported by experiments with depolarization-induced $\mathrm{Ca}^{2+}$ influx. A large influx of $\mathrm{Ca}^{2+}$ evoked by $100 \mathrm{mM} \mathrm{K}^{+}$produced neurotoxicity in cultured hippocampal neurons (Mattson et al., 1989). These studies did not add glutamate receptor or channel blockers to the superfusate; thus, the release of endogenous EAAs may have resulted in toxicity. Additionally, these cultures differ from ours in that they were only grown in culture for 1-2 $\mathrm{d}$ and thus probably had not developed a full compliment of NMDA receptors. Rothman et al. (1987), employing a morphological assay, observed that glutamate (1 $\mathrm{mM}, 30 \mathrm{~min}$ ) elicited delayed neurodegeneration, but $90-140$ $\mathrm{mm} \mathrm{K} \mathrm{K}^{+}$failed to elicit toxicity (see also Dubinsky and Rothman, 1991). Neurotoxicity experiments that elicit equivalent $\mathrm{Ca}^{2+}$ loading by either glutamate with voltage-gated $\mathrm{Ca}^{2+}$ channel antagonists present or depolarization with NMDA antagonists present would determine whether the increased $\left[\mathrm{Ca}^{2+}\right]_{i}$ elicited by these stimuli are effectively equivalent or whether $\mathrm{Ca}^{2+}$ entry via the NMDA channel is uniquely toxic.

Glutamate exposure activated both NMDA- and non-NMDAgated ion channels during the trigger phase. Calcium entry was in part through NMDA-gated channels, as indicated by $46 \%$ inhibition of the $\left[\mathrm{Ca}^{2+}\right]_{i}$ increase by AP-5. Calcium entry via non-NMDA channels has been reported (Gilbertson et al., 1991), but is unlikely here as CNQX, a non-NMDA receptor antagonist, had a minor effect on the response when applied subsequent to AP-5. This observation complements those of Michaels and Rothman (1990) who found that concentrations of CNQX sufficient to block glutamate-mediated inward current had little effect on glutamate-induccd toxicity (Michacls and Rothman, 1990). Inhibition of glutamate-induced $\mathrm{Ca}^{2+}$ influx by CNQX (Fig. 7C) may have resulted from antagonism at the glycine binding site of the NMDA channel (Kleckner and Dingledine, 1989; Pellegrini-Giampietro et al., 1989). Removal of extracellular $\mathrm{Na}^{+}$was an effective inhibitor of glutamate-induced $\left[\mathrm{Ca}^{2+}\right]_{i}$ transients, suggesting a role for $\mathrm{Na}^{+}$influx via the kainate/AMPA-gated ion channels (Collingridge and Lester, 1989). Reports employing either in vivo or in vitro assays of EAAmediated neurodegeneration have claimed neuroprotective effects for voltage-gated $\mathrm{Ca}^{2+}$ channel blockers (Nuglisch et al., 1990; Weiss et al., 1990). These agents did not reduce $\mathrm{Ca}^{2+}$ accumulation or immediate neurodegeneration during brief glutamate exposure (Weiss et al., 1990), suggesting that $\mathrm{Ca}^{2+}$ channel blockers may play a role in preventing additional release of endogenous EAAs following the initial insult. Other acute neurotoxicity studies performed in brain slices failed to demonstrate protective effects of $\mathrm{Ca}^{2+}$ channel blockers (Lehmann, 1987; Kass et al., 1988). Our experiments with nitrendipine confirm that dihydropyridine-sensitive $\mathrm{Ca}^{2+}$ channels have a limited, direct role in mediating glutamate-induced $\mathrm{Ca}^{2+}$ loads in single neurons. However, in some excitotoxicity paradigms dihydropyridine drugs have been shown to be neuroprotective (Abele et al., 1990; Sucher et al., 1991). The following sequence of events is likely. Glutamate activates both NMDA and nonNMDA receptors, but the limited $\mathrm{Ca}^{2+}$ permeability of nonNMDA-gated channels and the $\mathbf{M g}^{2+}$ block of NMDA-gated ion channels limit the $\mathrm{Ca}^{2+}$ influx. However, $\mathrm{Na}^{+}$influx via non-NMDA channels depolarizes the cell, relieving the voltagedependent $\mathrm{Mg}^{2+}$ block of NMDA channels, allowing a larger $\mathrm{Ca}^{2+}$ influx. This sequence of events has been proposed to initiate long-term potentiation (LTP) in the CAl layer of the hippocampus (Malenka et al., 1989).

The initial events in LTP are similar to the events hypothesized to occur in EAA toxicity; an NMDA-mediated $\mathrm{Ca}^{2+}$ load induces processes that lead to either long-lasting strengthening of synaptic transmission or neurodegeneration. Thus, the difference between physiologic and pathologic stimulation of EAA receptors is subtle. Presumably, the difference is intensity in that a $5 \mathrm{~min}, 100 \mu \mathrm{M}$ glutamate treatment initiates processes in addition to those that enhance synaptic transmission. A number of $\mathrm{Ca}^{2+}$-dependent enzymes are thought to be activated by an elevation in $\mathrm{Ca}^{2+}$ (Picone et al., 1989). These include protein kinases (Cumrine et al., 1990; Hara et al., 1990; Manev et al., 1990; Zivin et al., 1990; Wieloch et al., 1991), phospholipases (Siesjö, 1981), nitric oxide synthetase (Snyder and Bredt, 1991), endonucleases (Nicotera et al., 1990), and proteases (Lehmann, 1987; Siman et al., 1989). Other $\mathrm{Ca}^{2+}$-initiated toxic events may 
include the production of free radicals (Miyamoto et al., 1989; Siesjö et al., 1989), inhibition of protein synthesis (Raley-Susman and Lipton, 1990; Vornov and Coyle, 1991), and mitochondrial damage (Nicotera et al., 1990). A transient, yet intense stimulus may lead to an uncontrolled activation of one or all of these potentially lethal processes. We suggest that such activity may constitute the $\mathrm{Ca}^{2+}$-independent latent processes occurring prior to the secondary influx of $\mathrm{Ca}^{2+}$.

The key feature of the latent period is that the $\left[\mathrm{Ca}^{2+}\right]_{i}$ recovers to basal levels in $92 \%$ (59 of 64 ) of the neurons studied. This recovery indicates that the initial glutamate exposure does not irreversibly change $\left[\mathrm{Ca}^{2+}\right]_{i}$ homeostasis, but that a large $\mathrm{Ca}^{2+}$ load triggers processes that, once started, no longer require a maintained elevation of the $\left[\mathrm{Ca}^{2+}\right]_{i}$. Clearly, the $\left[\mathrm{Ca}^{2+}\right]_{i}$ homeostatic system has not been permanently damaged at this time. Since maintaining basal $\left[\mathrm{Ca}^{2+}\right]_{i}$ requires the concerted efforts of a number of regulatory and metabolic processes, the finding that this system is functional following glutamate exposure suggests that the neurotoxic process may be reversible at this time. During the latent phase, the neurons were typically quiescent with occasional interruptions by TTX-sensitive $\left[\mathrm{Ca}^{2+}\right]_{i}$ transients. These transients, while larger than those resulting from a single action potential, were not necessary for the delayed $\mathrm{Ca}^{2+}$ overload. The spikes appear to be a symptom rather than the cause of cell death, and perhaps result from partial depolarization of the membrane potential.

This study demonstrates that the mechanism leading to the secondary $\left[\mathrm{Ca}^{2+}\right]_{i}$ increase, once triggered, does not require the continued presence of $\mathrm{Ca}^{2+}$. Again, it is appropriate to draw a parallel to LTP. Malenka et al. (1989) postulated that the large $\mathrm{Ca}^{2+}$ load required to induce $L T P$ produces long-lasting changes in the postsynaptic neuron. Further, Malinow et al. (1989) have found that initiation of LTP requires activation of postsynaptic protein kinases, but presynaptic kinases appear to maintain LTP. Thus, the idea that a separate mechanism may be required for initiation versus maintenance of long-lasting change is exemplified by LTP. Furthermore, brief NMDA exposure will generate maintained $\left[\mathrm{Ca}^{2+}\right]_{t}$ gradients in the neuronal processes of hippocampal neurons that can be prevented by pretreatment with the C kinase inhibitor sphingosine (Connor et al., 1988). Gangliosides, which prevent the translocation of protein kinase $C$ to the membrane, have been reported to protect neurons from EAA-induced neurotoxicity (Favaron et al., 1988; Carolei et al., 1991) and to reduce the duration of glutamate-induced $\mathrm{Ca}^{2+}$ loads (de Erausquin ct al., 1990). We have not, as yet, cxplored the possibility that sustained kinase activation underlies the $\mathrm{Ca}^{2+}$ overload induced by glutamate. That initiation of delayed neurotoxicity may be separated mechanistically and temporally from the mediation of toxicity is consistent with our findings.

Our data suggest that neuroprotective agents directed at the latent phase should be aimed at non- $\mathrm{Ca}^{2+}$-dependent targets, such as a kinase catalytic subunit. Neurons have been successfully "rescued" following exposure to glutamate with either NMDA receptor antagonists or removal of extracellular $\mathrm{Na}^{+}$ and $\mathrm{Ca}^{2+}$ (Rothman et al., 1987; Hartley and Choi, 1989; Manev et al., 1989; Levy and Lipton, 1990). Although we removed extracellular $\mathrm{Ca}^{2+}$ for 30 min following glutamate exposure, neurons were not protected from glutamate-induced toxicity. A difference between these studies and ours is that we record $\left[\mathrm{Ca}^{2+}\right]_{i}$ from a single neuron from among the many on the plate, specifically avoiding any clumps of cells, which is in contrast to the observation of prominent neurotoxicity in densely popu- lated neuronal aggregates (Choi et al., 1987). Additionally, we record for a $3 \mathrm{hr}$ window, whereas other neurotoxicity assays typically assess viability $24 \mathrm{hr}$ after glutamate exposure. Measuring neurotoxicity after $24 \mathrm{hr}$ in culture may emphasize the action of synaptic connections and secondary glutamate release from dying neurons in the culture (Rothman et al., 1987).

The delayed increase in $\left[\mathrm{Ca}^{2+}\right]_{i}$ we recorded during the $\mathrm{Ca}^{2+}$ overload phase appears similar to sustained $\left[\mathrm{Ca}^{2+}\right]_{i}$ increases recorded by others (Connor et al., 1988; de Erausquin et al., 1990; Glaum et al., 1990). Our recordings are unique because the sustained increase is separated from the initial $\left[\mathrm{Ca}^{2+}\right]_{i}$ transient elicited by glutamate by a latent period of low resting $\left[\mathrm{Ca}^{2+}\right]_{i}$ in $84 \%$ (26 of 31 ) of the neurons in which glutamate exposure produced a sustained increase in $\left[\mathrm{Ca}^{2+}\right]_{i}$. Identification of this latent period, when $\left[\mathrm{Ca}^{2+}\right]_{i}$ is at basal levels, interposed between the large $\mathrm{Ca}^{2+}$ trigger and $\mathrm{Ca}^{2+}$ overload may explain the poor correlation between $\left[\mathrm{Ca}^{2+}\right]_{i}$ levels and neurodegeneration when measured $20 \mathrm{~min}$ following glutamate exposure (Michaels and Rothman, 1990). Alternatively, these results and those presented here could be interpreted to indicate that other factors, in addition to $\mathrm{Ca}^{2+}$, are necessary for neuronal degeneration. The discrepancy between our results and those in which $\left[\mathrm{Ca}^{2+}\right]_{i}$ remained elevated following glutamate exposure is not explained by differences in stimulation protocol since repeated or prolonged glutamate exposure failed to produce sustained elevation in $\left[\mathrm{Ca}^{2+}\right]_{i}$ in our neurons. We recorded considerably longer than previous studies in which $\left[\mathrm{Ca}^{2+}\right]_{i}$ was measured, suggesting that with more time the observed $\left[\mathrm{Ca}^{2+}\right]_{i}$ increases in previous studies may also have recovered. Indeed, recordings shown by de Erasquin et al. (1990) do show trends toward recovery to basal $\left[\mathrm{Ca}^{2+}\right]_{i}$ levels. We also noted a longer recovery from the $\mathrm{Ca}^{2+}$ load in neurons exposed to glutamate in $\mathrm{Mg}^{2+}$ free buffer for $15 \mathrm{~min}$. The neuron may simply require longer times to recover from larger $\mathrm{Ca}^{2+}$ loads (Thayer and Miller, 1990). Whether the delayed $\left[\mathrm{Ca}^{2+}\right]_{i}$ increase is a symptom or a cause of glutamate-induced delayed neuronal death is not evident from this study. Neuronal death, as defined by loss of indicator dye, was never observed in a cell that did not first exhibit a delayed $\left[\mathrm{Ca}^{2+}\right]_{i}$ increase. This result does not necessarily implicate $\mathrm{Ca}^{2+}$ overload as the cause of cell death. Death may result from gradual loss of membrane integrity, first appearing as influx of $\mathrm{Ca}^{2+}$ ions, followed by efflux of the larger indo-1 molecule. Reversal of $\mathrm{Ca}^{2+}$ loading and possibly neurotoxicity at this late stage was variable. In some cases, removing extracellular $\mathrm{Ca}^{2+}$ allowed rapid recovcry to basal levels, suggesting that $\mathrm{Ca}^{2+}$ buffering and homeostatic mechanisms were intact. However, in other neurons removing extracellular $\mathrm{Ca}^{2+}$ allowed only very slow recovery, often requiring $20 \mathrm{~min}$ or longer to reach basal levels; in these neurons $\mathrm{Ca}^{2+}$ buffering and efflux capabilities were severely compromised. We speculate that the latter neurons were beyond rescue (Schanne et al., 1979). The former cells may be protected if the $\mathrm{Ca}^{2+}$ influx is found to pass through a specific channel and thus be amenable to pharmacologic blockade. Preliminary experiments have shown that application of either AP-5, nitrendipine, or $\mathrm{La}^{3+}$ had little effect on the delayed $\mathrm{Ca}^{2+}$ overload once the plateau had been established.

The three-phase model presented here suggests several pharmacologic sites at which glutamate-induced toxicity may be arrested. The triggering phase is clearly an important target as indicated by the neuroprotection afforded by glutamate receptor antagonists in a number of in vitro (Choi et al., 1988) and in 
vivo (Simon et al., 1984) models of neurodegeneration. However, as suggested by Manev et al. (1990), selective inhibition of pathological relative to physiological stimulation of glutamate receptors may be difficult. They have suggested that inhibition of $\mathrm{C}$ kinase may be a more selective target for antagonism of "abusive stimulation." This idea is consistent with a $\mathrm{Ca}^{2+}-\mathrm{ac}-$ tivated, but non- $\mathrm{Ca}^{2+}$-dependent target during the latent phase, as suggested by our results. Unfortunately, inhibition of $\mathrm{C}$ kinase may not avert all neurotoxic processes initiated by a $\mathrm{Ca}^{2+}$ load (Cumrine et al., 1990; Zivin et al., 1990; Wieloch et al., 1991). The delayed $\mathrm{Ca}^{2+}$ influx also suggests a possible target. The suitability of this influx as a neuroprotective target rests on two factors; whether the $\mathrm{Ca}^{2+}$ influx mediates the toxicity and whether the $\mathrm{Ca}^{2+}$ influx is mediated by specific ion channels that may provide pharmacologic targets.

The proposed model divides glutamate-induced $\left[\mathrm{Ca}^{2+}\right]_{i}$ changes that accompany neurotoxicity into three phases, providing a framework around which the cellular events leading to death may be elucidated, and the point of irreversible damage determined. Each phase presents a potential target for neuroprotection. The parallels between this model of glutamate-induced delayed neurotoxicity and LTP highlight the precarious balance between long-lasting changes in synaptic transmission and irreversible damage mediated by NMDA-gated $\left[\mathrm{Ca}^{2+}\right]_{i}$ increases.

\section{References}

Abele AE, Scholz KC, Scholz WK, Miller RJ (1990) Excitotoxicity induced by enhanced excitatory neurotransmission in cultured hippocampal neurons. Neuron 4:413-419.

Carolei A, Fieschi C, Bruno R, Toffano G (1991) Monosialoganglioside GMI in cerebral ischemia. Cerebrovasc Brain Metab Rev 3:134157.

Choi DW (1987) Ionic dependance of glutamate neurotoxicity. J Neurosci 7:369-379.

Choi DW (1990a) Cerebral hypoxia: some new approaches and unanswered questions. J Neurosci 10:2493-2501.

Choi DW (1990b) Methods for antagonizing glutamate toxicity. Cerebrovasc Brain Metab Rev 2:105-147.

Choi DW, Maulucci-Gedde M, Kriegstein AR (1987) Glutamate neurotoxicity in cortical cell culture. J Neurosci 7:357-368.

Choi DW, Koh J, Peters S (1988) Pharmacology of glutamate neurotoxicity in cortical cell culture: attenuation by NMDA antagonists. J Neurosci 8:185-196.

Cobbold PH, Rink TJ (1987) Fluorescence and bioluminescence measurement of cytoplasmic free calcium. Biochem J 248:313-328.

Collingridge GL, Bliss TVP (1987) NMDA receptors-their role in long-term potentiation. Trends Neurosci 10:288-293.

Collingridge GL, Lester RAJ (1989) Excitatory amino acid receptors in the vertebrate central nervous system. Pharmacol Rev 40:143-210.

Connor JA, Wadman WI, Hockberger PE, Wong RKS (1988) Sustained dendritic gradients of $\mathrm{Ca}^{2+}$ induced by excitatory amino acids in CA1 hippocampal neurons. Science 240:649-653.

Cumrine RC, Dubyak G, LaManna JC (1990) Decreased protein kinase $\mathrm{C}$ activity during cerebral ischemia and after reperfusion in the adult rat. J Neurochem 55:2001-2007.

de Erausquin GA, Manev H, Guidotti A, Costa E, Brooker G (1990) Gangliosides normalize distorted single-cell intracellular free $\mathrm{Ca}^{2+}$ dynamics after toxic doses of glutamate in cerebellar granule cells. Proc Natl Acad Sci USA 87:8017-8021.

Dubinsky JM, Rothman SM (1991) Intracellular calcium concentrations during "chemical hypoxia" and excitotoxic neuronal injury. J Neurosci 1 1:2545-2551

Faden AI, Demediuk P, Panter SS, Vink R (1989) The role of excitatory amino acids and NMDA receptors in traumatic brain injury. Science 244:798-800.

Favaron M, Manev H, Alho H, Bertolino M, Ferret B, Guidotti A, Costa E (1988) Gangliosides prevent glutamate and kainate neu- rotoxicity in primary neuronal cultures of neonatal rat cerebellum and cortex. Proc Natl Acad Sci USA 85:7351-7355.

Garthwaite G, Hajos F, Garthwaite J (1986) Ionic requirements for neurotoxic effects of excitatory amino acid analogues in rat cerebellar slices. Neuroscience 18:437-447.

Garthwaite J, Garthwaite G (1990) Mechanisms of excitatory amino acid neurotoxicity in rat brain slices. In: Excitatory amino acids and neuronal plasticity (Ben-Ari Y, ed), pp 505-518. New York: Plenum.

Gilbertson TA, Scobey R, Wilson M (1991) Permeation of calcium ions through non-NMDA glutamate channels in retinal bipolar cells. Science 251:1613-1615.

Giulian D, Vaca K, Noonan CA (1990) Secretions of neurotoxins by mononuclear phagocytes infected with HIV-1. Science 250:1593-1596.

Glaum SR, Scholz WK, Miller RJ (1990) Acute- and long-term glutamate-mediated regulation of $\left[\mathrm{Ca}^{++}\right]$in rat hippocampal pyramidal neurons in vitro. J Pharmacol Exp Ther 253:1293-1302.

Greenamyre JT, Penney JB, Young AB, D'Amato CJ, Hicks SP, Shoulson I (1985) Alterations in L-glutamate binding in Alzheimer's and Huntington's diseases. Science 227:1496-1499.

Grynkiewicz G, Poenie M, Tsien RY (1985) A new generation of $\mathrm{Ca}^{2+}$ indicators with greatly improved fluorescence properties. J Biol Chem 260:3440-3450.

Hara H, Onodera H, Yoshidomi M, Matsuda Y, Kogure K (1990) Staurosporine, a novel protein kinase $C$ inhibitor, prevents postischemic neuronal damage in the gerbil and rat. J Cereb Blood Flow Metab 10:646-653.

Hartley DM, Choi DW (1989) Delayed rescue of $N$-methyl-D-aspartate receptor-mediated neuronal injury in cortical culture. J Pharmacol Exp Ther 250:752-758.

Heyes MP, Mefford IN, Quearry BJ, Dedhia M, Lackner A (1990) Increased ratio of quinolinic acid to kynurenic acid in cerebrospinal fluid of D retrovirus-infected rhesus macaques: relationship to clinical and viral status. Ann Neurol 27:666-675.

Hollmann M, Hartley M, Heinemann S (1991) $\mathrm{Ca}^{2+}$ permeability of KA-AMPA-gated glutamate receptor channels depends on subunit composition. Science 252:851-853.

Kass IS, Cottrell JE, Chambers G (1988) Magnesium and cobalt, not nimodipine, protect neurons against anoxic damage in the rat hippocampal slice. Anesthesiology 69:710-715.

Kleckner NW, Dingledine R (1989) Selectivity of quinoxalines and kynurenines as antagonists of the glycine site on $N$-methyl-D-aspartate receptors. Mol Pharmacol 36:430-436.

Köhr G, Heinemann U (1989) Effects of NMDA antagonists on picrotoxin-, low $\mathrm{Mg}^{2+}$ - and low $\mathrm{Ca}^{2+}$-induced epileptogenesis and on evoked changes in extracellular $\mathrm{Na}^{+}$and $\mathrm{Ca}^{2+}$ concentrations in rat hippocampal slices. Epilepsy Res 4:187-200.

Lehmann A (1987) Pharmacologic protection against the toxicity of $N$-methyl-D-asparate in immature rat cerebellar slices. Neuropharmacology 26:1751-1761

Levy DI, Lipton SA (1990) Comparison of delayed administration of competitive and uncompetitive antagonists in preventing NMDA receptor-mediated neuronal death. Neurology 40:852-855.

MacDermott AB, Mayer ML, Westbrook GL, Smith SJ, Barker JL (1986) NMDA-receptor activation increases cystoplasmic calcium concentration in cultured spinal cord neurons. Nature 321:519-522.

Malenka RC, Kauer JA, Perkel DJ, Nicoll RA (1989) The impact of postsynaptic calcium on synaptic transmission-its role in long-term potentiation. Trends Neurosci 12:444-450.

Malinow R, Schulman H, Tsien RW (1989) Inhibition of postsynaptic PKC or CaMKII blocks induction but not expression of LTP. Science 245:862-866.

Manev H, Favaron M, Guidotti A, Costa E (1989) Delayed increases of $\mathrm{Ca}^{2+}$ influx elicited by glutamate: role in neuronal death. Mol Pharmacol 36:106-112.

Manev H, Costa E, Wroblewski JT, Guidotti A (1990) Abusive stimulation of excitatory amino acid receptors: a strategy to limit neurotoxicity. FASEB J 4;2789-2797.

Marcoux FW, Probert AW Jr, Weber ML (1990) Hypoxic neuronal injury in tissue culture is associated with delayed calcium accumulation. Stroke 2:III71-III74.

Mattson MS, Kater SB (1989) Development and selective neurodegeneration in cell cultures from different hippocampal regions. Brain Res 490:110-125.

Mattson MP, Guthrie PB, Kater SB (1989) A role for $\mathrm{Na}^{+}$-dependent 
$\mathrm{Ca}^{2+}$ extrusion in protection against neuronal excitotoxicity. FASEB J 3:2519-2526.

Mayer ML, MacDermott AB, Westbrook GL, Smith SJ, Barker JL (1987) Agonist- and voltage-gated calcium entry in cultured mouse spinal cord neurons under voltage clamp measured using arsenazo III. J Neurosci 7:3230-3244.

Michaels RL, Rothman SM (1990) Glutamate neurotoxicity in vitro: antagonist pharmacology and intracellular calcium concentrations. J Neurosci 10:283-292.

Milani D, Guidolin D, Facci L, Pozzan T, Buso M, Leon A, Skaper SD (1991) Excitatory amino acid-induced alterations of cytoplasmic free $\mathrm{Ca}^{2+}$ in individual cerebellar granule neurons: role in neurotoxicity. J Neurosci Res 28:434-441.

Miyamoto M, Murphy TH, Schnaar RL, Coyle JT (1989) Antioxidants protect against glutamate-induced cytotoxicity in a neuronal cell line. J Pharmacol Exp Ther 250:1132-1140.

Murphy SN, Thayer SA, Miller RJ (1987) The effects of excitatory amino acids on intracellular calcium in single striatal neurons in vitro. J Neurosci 7:4145-4148.

Nicotera P, Bellomo G, Orrenius S (1990) The role of $\mathrm{Ca}^{2+}$ in cell killing. Chem Res Toxicol 3:484-494.

Nuglisch J, Karkoutly C, Mennel HD, Rossberg C, Krieglstein J (1990) Protective effect of nimodipine against ischemic neuronal damage in rat hippocampus without changing postischemic cerebral blood flow. J Cereb Blood Flow Metab 10:654-659.

Ogura A, Miyamoto M, Kudo Y (1988) Neuronal death in vitro: parallelism between survivability of hippocampal neurones and sustained elevation of cytosolic $\mathrm{Ca}^{2+}$ after exposure to glutamate receptor agonist. Exp Brain Res 73:447-458.

Olney JW (1.978) Neurotoxicity of excitatory amino acids. In: Kainic acid as a tool in neurobiology (McGeer EG, Olney JW, McGeer PL, eds), pp 95-121. New York: Raven.

Pellegrini-Giampietro DE, Galli A, Alesiani M, Cherici G, Moroni F (1989) Quinoxalines interact with the glycine recognition site of NMDA receptors: studies in guinea-pig myenteric plexus and in rat cortical membranes. Br J Pharmacol 98:1281-1286.

Peterson C, Neal JH, Cotman CW (1989) Development of $N$-methylD-asparate excitotoxicity in cultured hippocampal neurons. Dev Brain Res 48:187-195.

Picone CM, Grotta JC, Earls R, Strong R, Dedman J (1989) Immunohistochemical determination of calcium-calmodulin binding predicts neuronal damage after global ischemia. J Cereb Blood Flow Metab 9:805-811.

Raley-Susman KM, Lipton $\mathbf{P}$ (1990) In vitro ischemia and protein synthesis in the rat hippocampal slice: the role of calcium and NMDA reccptor activation. Brain Res 515:27-38.

Roe MW, Lemasters JJ, Herman B (1990) Assessment of fura-2 for measurements of cytosolic free calcium. Cell Calcium 11:67-73.

Rosenberg PA, Aizenman E (1989) Hundred-fold increase in neuronal vulnerability to glutamate toxicity in astrocyte-poor cultures of rat cerebral cortex. Neurosci Lett 103:162-168.

Rothman SM (1985) The neurotoxicity of excitatory amino acids is produced by passive chloride influx. J Neurosci 5:1483-1489.

Rothman SM, Thurston JH, Hauhart RE (1987) Delayed neurotoxicity of excitatory amino acids in vitro. Neuroscience 22:471-480.
Schanne FAX, Kane AB, Young EE, Farber JL (1979) Calcium dependence of toxic cell death: a final common pathway. Science 206: 700-702.

Siesjö BK (1981) Cell damage in the brain: a speculative synthesis. J Cereb Blood Flow Metab 1:155-185.

Siesjö BK, Bengtsson F (1989) Calcium fluxes, calcium antagonists, and calcium-related pathology in brain ischemia, hypoglycemia, and spreading depression: a unifying hypothesis. J Cereb Blood Flow Metab 9:127-140.

Siesjö BK, Agardh C-D, Bengtsson F (1989) Free radicals and brain damage. Cerebrovasc Brain Metab Rev 1:165-211.

Siman R, Noszek JC, Kegerise C (1989) Calpain I activation is specifically related to excitatory amino acid induction of hippocampal damage. J Neurosci 9:1579-1590.

Simon RP, Swan JH, Griffiths T, Meldrum BS (1984) Blockade of $\mathrm{N}$-methyl-D-asparate receptors may protect against ischemic damage. Science 226:850-852.

Snyder SH, Bredt DS (1991) Nitric oxide as a neuronal messenger. Trends Pharmacol 12:125-128.

Sucher NJ, Lei SZ, Lipton SA (1991) Calcium channel antagonists attenuate NMDA receptor-mediated neurotoxicity of retinal ganglion cells in culture. Brain Res 297:297-302.

Thayer SA, Miller RJ (1990) Regulation of the intracellular free calcium concentration in single rat dorsal root ganglion neurones in vitro. J Physiol (Lond) 425:85-115.

Thayer SA, Murphy SN, Miller RJ (1986) Widespread distribution of dihydropyridine-sensitive calcium channels in the central nervous system. Mol Pharmacol 30:505-509.

Thayer SA, Sturek M, Miller RJ (1988) Measurement of neuronal $\mathrm{Ca}^{2+}$ transients using simultaneous microfluorimetry and electrophysiology. Pfluegers Arch 412:216-223.

Turski L, Bressler K, Rettig K-J, Löschmann P-A, Wachtel H (1991) Protection of substantia nigra from MPP + neurotoxicity by $N$-methyl-D-aspartate antagonists. Nature 349:414-418.

Vornov JJ, Coyle JT (1991) Glutamate neurotoxicity and the inhibition of protein synthesis in the hippocampal slice. J Neurochem 56:996-1006.

Wahl M, Lucherini MJ, Gruenstein E (1990) Intracellular $\mathrm{Ca}^{2+}$ measurement with indo- 1 in substrate-attached cells: advantages and special considerations. Cell Calcium 11:487-500.

Weiss JH, Hartley DM, Koh J, Choi DW (1990) The calcium channel blocker nifedipine attenuates slow excitatory amino acid neurotoxicity. Science 247:1474-1477.

Wieloch T, Cardell M, Bingren H, Zivin J, Saitoh T (1991) Changes in the activity of protein kinase $\mathrm{C}$ and the differential subcellular redistribution of its isozymes in the rat striatum during and following transient forebrain ischemia. J Neurochem 56:1227-1235.

Young AB, Greenamyre JT, Hollingsworth Z, Albin R, D'Amato C Shoulson I, Penney JB (1988) NMDA receptor losses in putamen from patients with Huntington's disease. Science 241:981-983.

Yuste R, Katz LC (1991) Control of postsynaptic $\mathrm{Ca}^{2+}$ influx in developing neocortex by excitatory and inhibitory neurotransmitters. Neuron 6:333-344.

Zivin JA, Kochhar A, Saitoh T (1990) Protein phosphorylation during ischemia. Stroke 21:III117-III121. 